\title{
TRES FAMILIAS ANȘĀRÍES DE ÉPOCA ALMOHADE
}

\author{
THREE ANȘĀRI FAMILIES IN THE ALMOHAD PERIOD
}

\author{
MARÍA LUISA Ávila \\ Escuela de Estudios Árabes, CSIC
}

\begin{abstract}
Se reconstruyen en este artículo las familias Banū 1-Ṭaylasān, Banū 1-Šarrāt y Banū Ayyaš y se estudian las relaciones de parentesco establecidas entre ellas mediante una estrategia de alianzas matrimoniales diseñada por Abū l-Qāsim al-Šarrāṭ. Se aprecia cómo estos lazos familiares van estrechamente unidos a las relaciones de transmisión del saber, especialmente hadiz y ciencias coránicas. Se analizan asimismo las nisbas anșāríes, posiblemente adoptadas tardíamente, que exhiben todos ellos.
\end{abstract}

Palabras clave: familia; parentesco; anșāríes; jazraŷíes; awsíes; transmisión del conocimiento; almohades.
In this article I undertake the reconstruction of the Banū 1-Taylasān, the Banū 1-Sharrāt and the Banū 'Ayyash families, as well as the study of the relationships between them by means of a strategy of marriage alliances that was designed by Abū l-Qāsim al-Sharrāt. This study demonstrates that these family ties are intimately linked to the transmission of knowledge, especially Hadtīh and Koranic Sciences. I also analyse the Ansāari nisba-s which may have been adopted at a later stage.

Key words: Family; Kinship; Anșārīs; Khazrajīis; Awsīs; Transmission of knowledge; Almohads.

En los siglos VI-VII/XII-XIII, en pleno dominio almohade en al-Andalus, se produce un florecimiento de las ciencias, destacando grandes figuras en distintas ramas del saber. Entre ellas encontramos a dos ulemas sobresalientes tanto en el campo del hadiz como en el de los estudios coránicos. Se trata de Abū l-Qāsim Ibn al-Šarrāṭ y de su nieto Abū l-Qāsim Ibn al-Ṭaylasān, más conocido este último por su mayor producción bibliográfica y, sobre todo, por haber servido de fuente a Ibn al-Abbār en la redacción de su Takmila. Fuente de otro autor biográfico, Ibn 'Abd al-Malik al-Marrākuš̄i, es Ibn 'Ayyāš, descendiente también de Ibn al-Šarrāt. Estudiando las biografías de estos tres ulemas y sus antecedentes familiares se puede reconstruir una red de lazos familiares y de transmisiones que llega hasta época nazarí y que merece la pena señalar. 


\section{Banū l-Ṭaylasān al-Awsī}

La familia fue conocida en principio como Banū Sulaymān, aunque llama la atención que no se sepa nada de ningún miembro hasta Ahmad (cuadro n. ${ }^{\circ}$ 3), a quien se debe el cambio de nombre por Ibn al-Ṭaylasān. La palabra taylasān, que tiene su origen en el persa tālišs/tālišān, se pronuncia también taylisān y tạlusān (pl. țayälis y țayālisa); otra variante es țalisān. El țaylasān es un velo de muselina, que se echaba sobre la cabeza o sobre los hombros y que, según Dozy, era propio sobre todo de juristas y gente distinguida ${ }^{1}$. Podía ser de lino fino, lana e incluso de piel de cabra o camello. Este țaylasān de los jueces, que era negro en principio, podía sustituirse por otro chal, la tarha, que también podía ser blanco. Fue usado por los judíos, aunque, según Y.K. Stillman ${ }^{2}$, desde el principio de las conquistas islámicas se legisló prohibiendo que los pueblos conquistados vistieran como los árabes, en parte por un problema de seguridad y en parte por mantener una jerarquía social. Se prohibió a los dimmíes vestir tocados como el 'imāma, el aṣb y el taylasān, así como indumentaria árabe militar y otras ropas. Cristianos, judíos, zoroastras y sabeos tuvieron que vestir un cinturón distintivo (zunnār) y en época abbāsí fueron además impelidos a vestir țayālis de color miel, el mismo color de los turbantes, en caso de que los llevaran. También había de ser de diferente color la qalansuwa de los no musulmanes.

El țaylasān fue tema de una obra de al-Suyūṭi ${ }^{3}$. Dice este autor haber escrito su libro para defender la Sunna del Profeta y, aunque trata de demostrar que el uso del taylasān no constituye una innovación, según A. Arazi, editor del texto, en el fondo subyace el deseo de acallar a los detractores de la prenda y, sobre todo, de demostrar que su uso era prerrogativa del cadí šãfi'í, como muestra de la supremacía de este rito sobre los otros. Así había sido en época de los ayyūbíes y no por casualidad surge este texto en el período mameluco, cuando se pone en cuestión esta supremacía y se intenta sustituir por un sistema

${ }^{1}$ Dozy, R.P.A. (1820-1883), Dictionnaire détaillé des noms des vêtements chez les arabes, Beyrut [ca. 1969], 278-80. V. a. "Ṭarḥa", 254-262.

2 Stillman, Y.K., Arab dress: a short story: from the dawn of Islam to modern times, N.A. Stillman (ed.), Leiden, 2000.

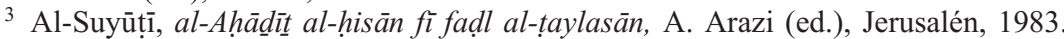
Debo esta cita a Manuela Marín, a quien agradezco la lectura de este artículo. Igualmente quiero mostrar mi agradecimiento a Mayte Penelas.

Al-Qanțara (AQ) XXX 2, julio-diciembre 2009, pp. 361-401 ISSN 0211-3589 
judicial cuatripartito, en el que estén representadas las otras escuelas ${ }^{4}$. La utilización de esta obra, ampliada con otras muchas fuentes, sirve a A. Arazi para realizar un detallado estudio sobre el taylasān, estableciendo diferentes tipos ${ }^{5}$. Entre ellos está el llamado por al-Suyūṭ̂ taylasān qinā' o taylasān muhannak o simplemente taylasān, que estaba constituido por un chal rectangular que, echado sobre el turbante, debía rodear la mandíbula inferior para replegarse sobre los hombros. Es este tipo, conforme con la Sunna, el de los ulemas. Fue precisamente bajo las dinastías turcas — selyuquíes, otomanos y mamelucos - cuando, en opinión de Y.K. Stillman, el țaylasān se convirtió en distintivo de cadíes y juristas.

M. Marín señala la forma de vestir como signo de pertenencia a un grupo social. En el caso de los ulemas la diferencia como grupo parece que se manifiesta sobre todo en el tocado, que varía según las zonas y la época. Afirma Dozy que en al-Andalus lo usaban indistintamente los personajes importantes y el pueblo, si bien sobre la cabeza sólo lo llevaban los šayjs más ilustres. Sin embargo, no debía de ser muy común en al-Andalus, al menos en época de Ibn al-Jaṭīb, pues, según un texto que recoge Marín, éste «se sorprendía al visitar en Cantoria a Jālid b. 'İsà al-Balawī y descubrir que iba vestido a la moda del Hị̂āaz, con un taylasān suelto» ${ }^{6}$. Tal vez fuera, como decía Dozy, vestimenta de personajes destacados, pues, en contradicción con el anterior testimonio y basándose también en Ibn al-Jațīb, M. ${ }^{a}$ I. Calero Secall dice que los cadíes granadinos «solían ir tocados con turbante ('imāma), distintivo de juristas, sabios y soldados en la Granada nazarí. Sobre los hombros del cadí descansaba un blanco țaylasān, especie de velo que a los orientales les cubría la cabeza. Vestían una durra ${ }^{\prime} a$, túnica larga y recta con anchas mangas de vivos colores, especialmente rojos y verdes» ${ }^{7}$.

${ }^{4}$ V. en la introducción a la obra el apartado titulado "Al-Ahādīth et la decadence shāfi'ite sous les mamlūks", 10-23.

5 Arazi, A., "Noms de vêtements et vêtements d'après al-Ahāaìt al-hisān fí faḍl al-țaylasān d'al-Suyūṭ̂”, Arabica, 23 (1976), 109-155. El autor se muestra muy crítico con el Dictionnaire détaillé de Dozy.

6 Marín, M., "Signos visuales de la identidad andalusí", en M. Marín (ed.), Tejer y vestir: de la Antigüedad al Islam, Madrid, 2001, 162.

7 Calero Secall, M.'I., Cadies del reino nazari de Granada: (estudio histórico-biográfico), Granada, 1984 (resumen de Tesis doctoral), 14.

Al-Qanțara (AQ) XXX 2, julio-diciembre 2009, pp. 361-401 ISSN 0211-3589 
Según refiere Ibn al-Abbār, el laqab de Ibn al-Ṭaylasān se lo puso a Ahmad (n. ${ }^{\circ}$ 3) su maestro Jalaf b. Yūsuf Ibn al-Abraš (m. 532/1143) ${ }^{8}$ porque, durante un tiempo en el que acudió a su círculo de estudio (maŷlis) en Sevilla, se presentaba cada día con ropas distintas a las del día anterior. Tenía este Ahmad una serie de vestidos de diversos colores y se preocupaba de doblarlos y de cuidarlos. Al verlo llegar, Ibn al-Abraš decía a sus discípulos: «Ha venido Ibn Sulaymān con otro țaylasān». Éste fue el motivo por el que los alumnos lo apodaron Taylasān y, a fuerza de repetirlo, fueron conocidos él y sus descendientes por Banū 1-Ṭaylasān, olvidándose la šuhra anterior ${ }^{9}$. ¿Llevaba realmente un țaylasān o, en una suerte de sinécdoque, la palabra, quizá escogida por su rima con Sulaymān, es utilizada como signo de vestimenta distinguida? Esta anécdota la recogen Ibn al-Abbār en la Takmila y al-Marrākušī en el Dayl ${ }^{10}$, mientras que al-Dahabī dice que su apodo se debía a su elegante indumentaria (li-ḥusn bizzati-hi) ${ }^{11}$.

Al prestigio científico de la familia, presente en las biografías de sus miembros (min bayt al- 'ilm), se une una elevada posición económica, que se puede deducir de esa variedad en el vestir que refleja la anterior anécdota. Pero además, su bonanza económica se indica en la biografía de Muhammad (n. $\left.{ }^{\circ} 4\right)$, en la que se dice que la familia fue bendecida con riquezas. Otro signo de su condición acomodada puede

${ }^{8}$ Gramático, natural de Santarén, que residió en varios lugares entre los que se citan Ceuta, Algeciras, Córdoba y Fez. Se lo relaciona con otros lugares, pero en su biografía no se hace referencia a esta estancia en Sevilla. V. al-Dabbī, Bugyat al-multamis fì ta'rìj riŷāl ahl al-Andalus, F. Codera y J. Ribera (eds.), Madrid, 1885, n. ${ }^{\circ}$ 722; Ibn Baškuwāl, Kitāb al-Ṣila, F. Codera (ed.), Madrid, 1882-1883, n. . 399; 'Iyāọ b. Mūsà, al-Gunya, M. Ŷarrār (ed.), Beirut, 1982, n. ${ }^{\circ}$ 54; Ibn al-Abbār, Tuhfat al-qādim, I. 'Abbās (ed.), Beirut, 1406/[1986], 22, n. ${ }^{o}$ 6; al-Muqtaḍab min Kitāb Tuhfat al-qādim, I. al-Abyārī (ed.), El Cairo, 1410/[1989], 66; al-Șafadī, Kitāb al-wāfì bi-l-wafayāt, M. al-Huŷairī (ed.), Wiesbaden, 1984, XIII, 367-68, n. ${ }^{\circ}$ 460; al-Suyūțī, Bugyat al-wu' ā fì tabaqāat al-lugawiyyìn wa-l-nuḥā, M. Abū l-Faḍl Ibrāhīm (ed.), El Cairo, 1964, I, 557, n. ${ }^{\circ}$ 1171; Marín, M., y Fierro, M., Sabios y santos musulmanes de Algeciras, Algeciras, 2004, 122, n. ${ }^{\circ} 74$.

9 Todavía a su hijo Muhammad se le da la šuhra Ibn Sulaymān. V. Ibn 'Abd al-Malik al-Marrākušī, al-D̃ayl wa-l-Takmila, VI, I. 'Abbās (ed.), Beirut, 1973, 40, n. ${ }^{\circ} 83$.

${ }^{10}$ En esta obra aparece no en su biografía, sino en la de su nieto (n. $\left.{ }^{\circ} 2\right)$. La anécdota ya fue recogida por M. Marín en "Nombre y sobrenombre: acerca de algunos apodos de los ulemas andalusíes", en Scripta in Honorem Enrique A. Llobregat Conesa, Alicante, 2000, 139-147.

11 El vocablo bizza tiene también el significado de vestido de honor (Kazimirski). V. al-Dahabī, Ta'rỉj al-Islām wa-wafayāt al-mašāhir wa-l-a 'lām, 'U.'A. Tadmūrī (ed.), Beirut, 1407-1424/[1987-2004], IL (años 571-580), 276, n. ${ }^{\circ} 297$.

Al-Qanțara (AQ) XXX 2, julio-diciembre 2009, pp. 361-401 ISSN 0211-3589 
ser el hecho de que Abū 1-Qāsim Ibn al-Ṭaylasān se dedicara en exclusiva a la ciencia, circunstancia resaltada por sus biógrafos.

Los Banū 1-Ṭaylasān eran anșāríes awsíes ${ }^{12}$. Recuérdese que fueron llamados así los miembros de las tribus de Aws y Jazraŷ, anteriormente Banū Qayla, que apoyaron a Muhammad en Medina. Se podría decir por tanto que son de rancio abolengo árabe/islámico, aunque, como ya se ha advertido, no se tiene noticia de su linaje hasta el siglo VI/XII. Se ha de señalar aquí que en la biografía de 'Abd Allāh b. Ahmad (n. ${ }^{\circ}$ 1) aparece la nisba como al-Awšì en las dos ediciones de la Takmila de Ibn al-Abbār y que uno de los editores, 'I. al-'Atṭār al-Ḥusaynī, la documenta como Ǔšì, patronímico de un lugar en la región de Fargāna ( $m a \bar{a}$ wara' al-nahr, cerca de Turquestán). Se trata de un error, que no se repite en las biografías de los otros Banū 1-Ṭaylasān.

Existen algunas dudas sobre los miembros de esta familia. M. Marín duda de que Ahmad (n. ${ }^{\circ} 3$ ) vaya en el lugar del árbol genealógico en el que lo he situado ${ }^{13}$, pero aparte de su nasab, especificado claramente por las fuentes, se refiere a él Ibn 'Abd al-Malik al-Marrākušī en la biografía de su nieto Ahmad (n. ${ }^{\circ}$ 2), al que llama «hijo de su hijo», mientras que Ibn al-Abbār dice que era ŷadd de Abū 1-Qāsim (n. ${ }^{\circ}$ 5). También al-Dahabī dice que Abū l-Qāsim era nieto suyo. Un argumento en contra de esta filiación podría ser la fecha de fallecimiento de su hijo Muhammad, tan sólo tres años posterior a la suya. Sin embargo, esta cercanía entre padre e hijo es explicable si atendemos a al-Dahabī, que califica al padre de longevo, mientras que, según al-Marrākušs̄i, el hijo muere prematuramente con 44 años lunares. Precisamente vemos que, contrariamente a lo que ocurre en tantas ocasiones, le reza la oración fúnebre su suegro.

Respecto a los hijos de este Aḥmad, 'Abd Allāh, Sulaymān y Muhammad, Ibn 'Abd al-Malik, siempre presto a establecer relaciones familiares, duda de la información proporcionada por Ibn al-Zubayr y de que exista Sulaymān (ver n. ${ }^{\circ}$ 3), aunque los tres hijos están documentados en las fuentes. Además, parte de las noticias que sobre él recogen la Takmila y el Dayl proceden de su propio sobrino, Abū

12 Sobre los Anșār, Aws y Jazraŷ, v. s.v.v. $E I^{2}$, arts. W.M. Watt; Hasson, I., "Contribution à l'étude des Aws et des Hazrağ", Arabica, 36 (1989), 1-35.

13 Marín, M., "Parentesco simbólico y matrimonio entre los ulemas andalusíes", Al-Qantara, XVI, 2 (1995), 341, nota 26.

Al-Qanțara (AQ) XXX 2, julio-diciembre 2009, pp. 361-401 ISSN 0211-3589 
1-Qāsim (n. ${ }^{\circ}$ 5), quien dice haber estudiado con él varias obras, que especifica, y también haber asistido a su entierro.

Era usual entre las familias de sabios utilizar a las mujeres como nexo de unión con otras familias pertenecientes al mismo grupo y así el discípulo matrimonia con cierta frecuencia con la hija del maestro, convirtiéndose en sihr de éste y viceversa. En este caso el entronque de los Banū 1-Ṭaylasān con los Banū 1-Šarrāṭ se hace a través del matrimonio de Abū 'Abd Allāh Muhammad b. Ahmad (n. ${ }^{\circ}$ 4) con Fātima, hija de Abū 1-Qāsim 'Abd al-Raḥmān b. Muhammad b. Gālib al-Šarrāt, sabio de gran prestigio en los estudios coránicos y en el hadiz. Sobre las relaciones de mușāhara o parentesco afín existe un interesante artículo de M. Marín, citado anteriormente, en el que se hace referencia a estas tres familias.

Fruto de este matrimonio entre Muhammad y Fātima son Aḥmad y Abū l-Qāsim al-Qāsim, sin duda el miembro de más renombre de la familia. Aunque parece que los dos hermanos estudian con los mismos maestros, la diferencia entre ellos estriba en que Ahmad se inclinó más por el derecho — redacción de contratos ('aqd al-šurūt) y partición de herencias (farā'iḍ) —, mientras que Abū 1-Qāsim se dedicó al Corán y al hadiz, materia sobre la que versan algunas obras de las nueve que sabemos que compuso. Su celebridad se debe sin duda no sólo a su producción escrita, sino a la transmisión de esas obras por parte de ulemas posteriores. No es ajeno a su fama el hecho de que Ibn al-Abbār lo conociera y usara como fuente alguna de sus obras o la circunstancia de que Muḥammad b. 'Ayyāšs, pariente y transmisor suyo, fuera fuente de Ibn 'Abd al-Malik al-Marrākušî. La familia es de Córdoba, pero cuando se produce la conquista de la ciudad por Fernando III, Aḥmad y al-Qāsim, los dos únicos que viven en esa época, se ven obligados a trasladarse a Málaga al final del año 633/1236. Allí se establece al-Qāsim, que se supone que continúa con la misma actividad, pues fue jațib y encargado de la oración en una de las tres mezquitas de la ciudad, la de la aljama de la Alcazaba. El hecho de la pronunciación de la juṭba en esta mezquita lo explica Calero, que ha estudiado cómo los almohades impulsaron el crecimiento urbanístico de Málaga, en parte como propaganda y en parte como necesidad ante el aumento de la población. Ampliaron y reformaron la Mezquita Mayor, y la oración del viernes y la juṭba se realizaban simultáneamente en tres mezquitas de la ciudad: la Mezquita Mayor, 
la Mezquita aljama del arrabal oriental y la de la Alcazaba ${ }^{14}$. Ahmad, el hermano de al-Qāsim, se trasladará posteriormente a Granada.

\section{Banū Gālib al-Šarrāṭ al-Anșārī}

Se ha señalado la relevancia de la figura de Abū l-Qāsim Ibn al-Ṭaylasān, pero igualmente prestigioso debió de ser en su época Abū l-Qāsim Ibn al-Šarrāṭ (n. ${ }^{\circ} 8$ ), que además es el centro y personaje clave de estas familias con sus estrategias matrimoniales.

La familia lleva la nisba anșārī, sin más especificaciones, y es Abū 1-Qāsim el primer miembro destacado en el ámbito del saber. Se forma en lecturas coránicas, hadiz y adab con diversos maestros hasta conseguir la primacía en su tiempo, sin que parezca haber recibido el menor empuje familiar para ello. Con frecuencia vemos, y se advierte en la siguiente generación, cómo la influencia de la familia es determinante a la hora de pertenecer al círculo de los ulemas y entrar en las cadenas de transmisión de la ciencia, y, sin embargo, nada se sabe del padre y de los antepasados de Abū l-Qāsim. Tampoco se tienen noticias de su hermano Ahmad.

Su hijo Abū Bakr Gālib (n. ${ }^{\circ}$ 10) siguió los pasos paternos adquiriendo una sólida formación en Corán, hadiz y gramática, que le permitió dedicarse a transmitir a otros. Además, Abū 1-Qāsim tuvo dos hijas, Umm al-Fath Fāṭima (n. ${ }^{\circ}$ 9) y otra de nombre desconocido. Fătima es una de las pocas mujeres sabias andalusíes que conocemos y su biografía parece diferenciarse poco de las de los otros ulemas que aparecen en este trabajo. Transmite varias obras de su padre a su hijo Abū l-Qāsim Ibn al-Taylasān (n. ${ }^{0}$ 5), estudia además con otros dos maestros y le otorga licencia Abū Marwān Ibn Masarra. En apariencia es la biografía normal de cualquier ulema, pero analizando un poco los datos, se ve que existe una relación especial de este sabio

${ }^{14}$ Calero Secall, M.'a., "Algunas fetuas sobre la duplicidad de las aljamas andalusíes", en L'urbanisme dans l'Occident musulman au Moyen Âge: aspects juridiques, actes recueillis et préparés par Patrice Cressier, Maribel Fierro et Jean-Pierre Van Staëvel, Madrid, 2000, 125-140, concretamente 129 sobre la duplicidad y 136 sobre las aljamas de las alcazabas. Cf. también Calero Secall, M. ${ }^{\mathrm{a}}$. y Martínez Enamorado, V., Málaga, ciudad de al-Andalus, Málaga, 1995, 219-225, sobre la mezquita de la Alcazaba. En 220 recoge los que fueron juțabä' en ella, entre ellos Ibn al-Ṭaylasān (n. ${ }^{\circ}$ 5). Sobre la existencia en el siglo XIV de tres juțabä' simultáneos, v. 197-200.

Al-Qanțara (AQ) XXX 2, julio-diciembre 2009, pp. 361-401 ISSN 0211-3589 
con la familia, pues es el que, de recién nacida, le impone el nombre y la bendice, y que los otros maestros con los que estudia no son los grandes expertos en lectura coránica que enseñaron a su hermano, sino un asceta no muy conocido, al que no he podido localizar, y otro ciego. El hecho de que uno de sus maestros tuviera esta discapacidad puede entrar dentro de lo normal en esta disciplina ${ }^{15}$, aunque tampoco debemos descartar que, tratándose de una mujer, se acudiera a un maestro ciego más por su condición de tal que por su capacitación intelectual. De esta forma se limitaba el contacto físico con varones ajenos a la familia ${ }^{16}$. De su otra hermana no se conserva biografía y es probable que, así como desconocemos su nombre, no hubiéramos sabido nada de ella de no haber formado parte de las alianzas matrimoniales de su padre.

Independientemente de la diferente participación de estas dos mujeres en el mundo del saber, ambas adquieren relevancia como vínculo de unión de la familia de los Banū Gālib con los Banū l-Ṭaylasān y los Banū 'Ayyāš, mediante su matrimonio con dos ulemas discípulos de su padre: Fātima, como ya se ha dicho, contrajo matrimonio con Abū 'Abd Allāh Muḥammad b. Aḥmad b. Muhammad b. Sulaymān b. Muhammad b. Sulaymān al-Anșārī al-Awsī, conocido por Ibn al-Ṭaylasān y por Ibn Sulaymān (n. $\left.{ }^{\circ} 4\right)$, mientras que su hermana fue esposa de Abū 'Abd Allāh Muhammad b. Aḥmad b. Jalaf b. 'Ayyāšs al-Anșārī al-Jazraŷī al-Šintiyālì (n. $\left.{ }^{\circ} 13\right)$. Esta relación es paradigmática de las estrategias matrimoniales que se establecen dentro del grupo de los ulemas, ligadas a la transmisión del saber, relación que ha sido estudiada por M. Marín en el artículo citado anteriormente en el que aparece esta familia como ejemplo de las «conexiones entre parentesco por matrimonio y transmisión». Las relaciones de muṣāhara o parentesco afín establecen una estrecha vinculación entre los hombres emparentados, como se señala en el trabajo mencionado. El término

15 M. Marín ha señalado la existencia de muchos almocríes ciegos, tanto en al-Andalus como en el resto del mundo islámico. V. Marín, M., "La actividad intelectual", en M. JJ. Viguera Molins (coord.), "Los reinos de Taifas: al-Andalus en el siglo XI", Historia de España Menéndez Pidal, VIII-1, Madrid, 1994, 508.

16 Recuérdense otros métodos de limitar este contacto, como la interposición de una cortina entre maestro y discípula, en Ávila, M.'L., "Las mujeres sabias en al-Andalus", en M. J. Viguera (ed.), La mujer en al-Andalus: reflejos históricos de su actividad y categorías sociales, Madrid-Sevilla, 1989, 170, n. ${ }^{\circ}$ 78, y Marín, M., Mujeres en al-Andalus, EOBA, XI, Madrid, 2000, 647.

Al-Qanțara (AQ) XXX 2, julio-diciembre 2009, pp. 361-401 ISSN 0211-3589 
empleado para definirlas, sihr, alude al suegro, al cuñado o al yerno, pero también a otros parentescos más lejanos. Centrándonos en el caso de estas familias, en la biografía que Ibn 'Abd al-Mālik al-Marrākušĩ dedica a Abū Ŷa far Aḥmad Ibn al-Ṭaylasān (n. ${ }^{\circ}$ 2), se refiere a Abū 'Abd Allāh Ahmad b. 'Ayyāš como sihr tanto de Abū 1-Qāsim 'Abd al-Raḥmān b. Muhammad al-Šarrāt (n. ${ }^{\circ}$ 8), como de su hijo Abū Bakr Gālib (n. ${ }^{\circ}$ 10), cuando era suegro de la hija y hermana de éstos. Por tanto la palabra hace referencia también a consuegro. En este sentido es empleada en la biografía del $n^{\circ}{ }^{\circ} 3$ para referirse a Abū 1-Qāsim al-Šarrāt. Parece bien claro que șihr es cualquier tipo de pariente afín.

Volviendo a los Banū 1-Šarrāt, de la línea del desconocido Ahmmad, tenemos a Muhammad, también llamado Hamad o Hamū (n. $\left.{ }^{\circ} 11\right)$. También sabemos de un tâlib de Málaga llamado Abū Muhammad 'Abd Allāh b. Muhammad al-Šarrāt (n. ${ }^{\circ}$ 7), que probablemente sea descendiente de este Hamad. No aparece citado por M. ${ }^{\mathrm{a}}$ I. Calero Secall entre los talaba de Málaga y para la época en que vive - fallece con posterioridad al 700/1300-01-, la institución de los țalaba, propagandistas al servicio del califa almohade en la capital o al servicio de los gobernadores en cada ciudad, ha desaparecido, según afirma E. Fricaud ${ }^{17}$. En el apéndice biográfico puede verse la diferencia entre este ulema y los restantes aquí recogidos en cuanto a las disciplinas cultivadas, su actividad poética, su oficio de kātib y sobre todo, su relación con el poder y su intervención en intrigas políticas.

\section{Banū 'Ayyāš al-Jazraŷī}

Al igual que ocurre con los Banū 1-Ṭaylasān y los Banū Gālib, no se tiene noticia del epónimo de esta familia, 'Ayyāš, ni de sus descendientes hasta el siglo VI/XII, época en la que aparecen 'Ubayd Allāh (n. $\left.{ }^{\circ} 17\right)$ y Muhammad (n. $\left.{ }^{o} 13\right)^{18}$. Este último, aparte de ser el primer

17 Calero Secall, M.a.', "Málaga almohade: políticos y ulemas", en M.L. Ávila y M. Fierro (eds.), Biografias almohades II, EOBA, X, Madrid-Granada, 2000, 318 (la relación de țalaba está tomada de Udabā' Mālaqa, de Ibn 'Askar), y Fricaud, E., "Les talaba dans la société almohade", Al-Qanțara, XVIII, 2 (1997), 331-387.

18 Existe un Abū Bakr 'Ayyāš b. al-Jalaf b. 'Ayyāš b. Muhriz al-Muqri' (m. 510/1116-17), natural de Badajoz e instalado en Sevilla, que transmitió las qirā'àt del almocrí Abū 'Abd Allāh al-Magāmī, que tal vez podría entroncarse en el árbol genealógico

Al-Qanțara (AQ) XXX 2, julio-diciembre 2009, pp. 361-401 ISSN 0211-3589 
miembro destacado de la familia, fue el que entroncó con los Banū Gālib al-Šarrāt al casar con una hija de 'Abd al-Raḥmān de nombre desconocido. Llama la atención en esa familia que una de las hijas se dedicara al saber ${ }^{19}$, mientras que de la otra no se conoce ni el nombre.

Este Muhammad, al que me he referido, y también su hijo 'Ayyāš fueron conocidos con el patronímico al-Šintiyālī, probablemente referido a Chinchilla de Montearagón, en aquel entonces perteneciente a Murcia y actualmente en la provincia de Albacete. No hay, pues, que descartar que tengan su origen en esa ciudad, aunque Muhammad parece bien afianzado en Córdoba, en cuya mezquita fue imán alrededor de treinta años, y la relación de su hijo 'Ayyāš con la capital es indudable; éste llevaba además la nisba al-Qurțubī, aunque finalmente acabó en Málaga, al igual que otros miembros de las familias aquí estudiadas y de otras muchas que no tuvieron otro remedio que abandonar la capital ante el avance cristiano. De él precisamente se dice que fue el último jațīb que predicó en la mezquita aljama de Córdoba.

Los Banū 'Ayyāš eran anșāríes jazraŷíes, como también eran anșāríes las otras dos familias. Conviene fijarse en la nisba tribal, pues hay varias familias con el mismo nombre y podrían ser confundidos con los Banū 'Ayyāšs tuŷībíes, que destacaron como secretarios de los califas almohades ${ }^{20}$ o con los kināníes, o 'abdíes.

El nombre de los descendientes conocidos de 'Ayyāš b. Muhammad, todos de nombre Muhammad, puede inducirnos a cierta confusión, que hay que tratar de aclarar.

El primer Muhammad que aparece es su hijo, cuyos nasab y kunya, Muḥammad b. 'Ayyāš b. Muḥammad b. Aḥmad b. Jalaf b. 'Ayyāš al-Jazraŷi al-Qurțubī, Abū 'Abd Allāh (n. ${ }^{\circ}$ 14), nos proporciona al-Ŷazarī. Parece que no hay duda sobre su identidad, pues en la biografía ofrecida por este biógrafo se especifica que era hijo de Abū

de esta familia, pero no creo que pertenezca a ella. V. su biografía en Ibn Baškuwāl, Kitāb al-Șila, n. ${ }^{0}$ 968; al-Dahabī, Ṭabaqāt al-qurrā', A. Jān (ed.), al-Riyād, 1418/1997, II, 742, n. ${ }^{\circ}$ 649, e Ibn al-Ŷazarī, Gāyat al-nihāya fi tạaquāt al-qurrā', G. Bergstraesser y O. Pretzl (eds.), Bagdad, 1932, I, 607 (2481).

19 Ver n. ${ }^{\circ} 9$.

${ }^{20}$ Se trata de Abū 'Abd Allāh Muhammad b. 'Abd al-'Azīz b. 'Abd al-Rahmān b. 'Ubayd Allāh b. 'Ayyāšs al-Tuŷībī y sus hijos Abū l-Qāsim 'Abd al-Rahmān y Abū Ŷafar Ahmad. V. sobre ellos Molina Martínez, L., "Instituciones administrativas: visires y secretarios", en M. J. Viguera Molins (coord.), "El retroceso territorial de al-Andalus. Almorávides y almohades", Historia de España Menéndez Pidal, VIII-2, Madrid, 1997, 164.

Al-Qanțara (AQ) XXX 2, julio-diciembre 2009, pp. 361-401 ISSN 0211-3589 
Bakr. Los datos biográficos de este Muhammad son escasos. Sólo sabemos que estudió (qara'a) con Qāsim b. Muḥammad Ibn al-Ṭaylasān al-Awsī, cuya relación de parentesco puede verse en el árbol genealógico, y que con él estudiaron (qara'a) 'Abd Allāh b. 'Alī b.

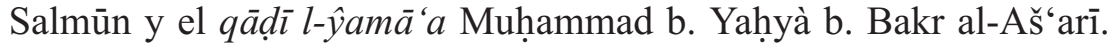

Muhammad tuvo un hijo, también de nombre Muhammad y de kunya Ảbū 'Abd Allāh, que fue cadí de Granada y que aparece en las fuentes mencionado indistintamente como:

a) Muḥammad b. 'Ayyāšs (Ihạța).

b) Muḥammad b. Muḥammad b. 'Ayyāš (al-Marqaba al-'ulyā, Durrat al-hiŷāl).

c) Muḥammad b. Muḥammad b. Muḥammad b. 'Ayyāš (Al-Durar al-kāmina).

No hay duda de que se trata de la misma persona, por el hecho de que el ejercicio del cadiazgo y su renuncia a él se mencionan en todas las fuentes. La circunstancia de que conozcamos a su antecesor en el cargo, Muhammad b. Yahyà b. Bakr al-Aš‘ arī, y a su sucesor, Abū Bakr Ahmad b. Muhammad b. Barțāl, y de que tengamos la relación de los cadíes nazaríes, descarta la posibilidad de padre e hijo ocupando el mismo cargo ${ }^{21}$. Sí es posible, sin embargo, que haya habido contaminación de otros datos de dos biografías. Las fechas del último, 688-759, hacen posible que fuera nieto de 'Ayyāš (572-640), pero no impiden tampoco que fuera bisnieto.

Se podría establecer que 'Ayyāš tuvo un hijo, Muḥammad (n. $\left.{ }^{\circ} 14\right)$, y un nieto, cadí de Granada, Muhammad b. Muḥammad (n. $\left.{ }^{\circ} 15\right)$, citado de forma abreviada por Ibn al-Jatīib y de forma más amplia de lo debido por Ibn Haŷar. Tal vez este último se confundió en el nasab por la existencia de un tercer descendiente Muhammad b. Muhammad b. Muḥammad b. 'Ayyāš, persona de menor relevancia, al que atribuyó los méritos de su padre.

La biografía de este o estos Muhammad parece diferenciarse de la compartida por sus antecesores y el resto de las otras familias. Al menos se resaltan aspectos distintos, como el ejercicio del cadiazgo. Al

${ }^{21}$ Dicha relación ha sido establecida por M. ${ }^{\mathrm{a}}$. Calero Secall en Cadies del reino nazarí, 8-9, y en "Cadíes supremos de la Granada nasrí", en Actas del XII Congreso de la UEAI (Málaga, 1984), Madrid, 1986, 135-160. Se puede ver también en "La justicia, cadíes y otros magistrados", en M. J. Viguera Molins (coord.), "El retroceso territorial de al-Andalus. El Reino nazarí de Granada (1232-1492): política, instituciones, espacio y economía", Historia de España Menéndez Pidal, VIII-3, Madrid, 2000, 377-78.

Al-Qanțara (AQ) XXX 2, julio-diciembre 2009, pp. 361-401 ISSN 0211-3589 
asumir el cargo de cadí e introducirse en el mundo del derecho, se concede más importancia al estudio del fiqh, aunque por familia se sigue recibiendo la tradición coránica.

Se ha hablado anteriormente de las relaciones de musāhara establecidas entre estas tres familias. Creo que existe una más. En la biografía de Abū l-Qāsim Ibn al-Ṭaylasān (n. o 5) dice Ibn 'Abd al-Malik que su maestro Abū 'Abd Allāh Ibn 'Ayyāš (n. $\left.{ }^{\circ} 14\right)$ era șihr de este Ibn al-Ṭaylasān (n. ${ }^{\circ} 5$ ), que era primo hermano de su padre por parte de madre. No creo que se trate de una equivocación o de un uso del vocablo sihr contrario al referido, pues el término empleado para sobrino o tío consanguíneo es qarīb. Así vemos que lo emplea el mismo al-Marrākušì unas páginas más adelante para referirse a Hamad o Hamū (n. $\left.{ }^{\circ} 11\right)$, hermano de la madre de al-Qāsim ${ }^{22}$. Creo que la frase no requiere interpretación y simplemente debemos creer que el número 14 se casó con una hija del número 5 .

Tanta relación familiar induce a error a algún autor, como al-Ŷazarī, que dice que Ibn al-Ṭaylasān (n. ${ }^{\circ}$ 5) era nieto por parte de madre de Muḥammad b. Aḥmad b. Jalaf b. 'Ayyāš (n. ${ }^{0} 13$ ), que era maestro suyo, cuando en realidad este sabio estaba casado con la hermana de su madre ${ }^{23}$. El nieto de éste, Muḥammad b. 'Ayyāš b. Muhammad (n. ${ }^{0}$ 14), fue discípulo y yerno de Ibn al-Ṭaylasān. Vemos, pues, en este caso cómo los conocimientos se transmiten de abuelo a nieto a través de un tercero que también forma parte de la red familiar, con lo cual esa parcela del saber sigue siendo controlada por la familia.

De la biografía del n. ${ }^{\circ} 13$ en el Dayl de al-Marrākušĩ parece desprenderse que éste tuvo un hermano, Abū 1-Qāsim 'Abd al-Raḥmān, padre de un tal Abū 'Imrān, que sería transmisor de su tío Muhammad. Seguramente este Abū 'Imrān se llamaría Mūsà, que es el ism asociado a esta kunya, pero no he encontrado la biografía de ninguno de los dos.

Por último, Abū Marwān 'Ubayd Allāh b. 'Abd Allāh b. Jalaf b. 'Ayyāš al-Anșāî̄ (n. ${ }^{\circ}$ 17), perteneciente a otra rama de los Banū

${ }^{22}$ Dayl, V-2, 557. El término qarīb, pariente cercano, se emplea para expresar distintos grados de parentesco. Así, por ejemplo, en Dayl, I (2), 473, n. ${ }^{\circ} 714$, se dice que Abū 'Abd Allāh Muḥammad b. Muḥammad b. 'Abd al-'Azīz era qarìb de sus primos segundos (sexto grado) Abū 1-Jattāb Ahmad b. Muhammad b. 'Umar b. Muhammad b. Wāŷib y Abū l-Ḥasan Ahmad b. Muḥammad b. 'Umar b. Muhammad b. Wàŷib, que a su vez eran entre sí primos hermanos en cuarto grado.

${ }^{23}$ Ibn al-Ŷazarī, Gāyat al-nihāya, II, 23, n. ${ }^{\circ} 2601$.

Al-Qanțara (AQ) XXX 2, julio-diciembre 2009, pp. 361-401 ISSN 0211-3589 
'Ayyāš, parece el más alejado del círculo familiar. Contemporáneo de Abū Ŷa 'far Ibn al-Ṭaylasān (n. ${ }^{\circ}$ 3) y de Abū l-Qāsim al-Šarrāt (n. $\left.{ }^{\circ} 8\right)$, nada indica que haya tenido una especial relación con ellos. Para empezar, vive en otra ciudad, Málaga, y quizá sea este alejamiento del núcleo el que haya impedido su transmisión de los dos mencionados, así como el hecho de que ninguno de los de las siguientes generaciones haya acudido a él. Por otra parte, parece que sus conocimientos se limitaban a una transmisión de Ibn 'Attāb.

De las tres familias, son los Banū 'Ayyāš los únicos que subsisten hasta 817/1414. En las otras se observa, a partir de la tercera generación de las aquí señaladas, una falta de descendientes varones, ante la cual hay que preguntarse si realmente no los tuvieron o si, al reducirse el territorio bajo dominio musulmán, se trasladaron al otro lado del Estrecho. Allí tal vez se habrían dedicado a otra actividad y pasado inadvertidos. Muhammad Ibn Ayyāš, el cadí de Granada (n. ${ }^{\circ}$ 15), es también descendiente de Abū 1-Qāsim Ibn al-Taylasān y de Abū l-Qāsim Ibn Gālib al-Šarrāṭ. Las tres familias confluyen en él y con su hijo parece que se extinguen.

\section{La nisba al-Anșārī}

Respecto a su origen, hemos visto una característica común a estas tres familias: los Banū 1-Ṭaylasān eran anșāríes de Aws, los Banū 'Ayyāš también eran anșāríes de Jazraŷ y los Banū 1-Šarrāt reciben la nisba amplia de al-Anșāīi, sin especificar. Son familias aparentemente de honda raigambre árabe, descendientes de aquellos que apoyaron al Profeta, pero sin antepasados documentados antes del siglo VI. Esto ocurre en otras familias relevantes, como los Banū 1-Ŷadd, fihríes de Niebla y Sevilla, de los que no se tiene noticia hasta el siglo V/XI, o los Banū Manzūr, qaysíes de Sevilla, emigrados a Málaga. Este fenómeno podría explicarse, como ya aventuré en otra ocasión, por un origen no árabe de la familia y una posible conversión e integración tardía en la sociedad islámica, o, como sugiere M. Marín, por una integración tardía no en la sociedad islámica, sino en los círculos científicos y políticos ${ }^{24}$. Resulta por tanto algo sospechoso este linaje

${ }^{24}$ Sobre estas teorías y estas dos familias, v. Marín, M., "Abū Bakr Ibn al-Ŷadd y su familia", en Biografías Almohades, I, EOBA, IX, 1999, 223-259, y Ávila, M.ª., "Los 
anșārí y quizá haya que pensar en la fabricación de una genealogía que ennoblezca a la familia. Puestos a adoptar una nisba que acreciente el prestigio religioso de la familia, qué mejor que una tan islámica como al-Anșāī para unos individuos que consagraron sus vidas al estudio y enseñanza del Corán. M. Fierro, que ha dedicado varios artículos al estudio de la nisba al-Anșārī en al-Andalus, señala cómo a partir del siglo V/XI se produce un aumento de esta nisba que denomina religiosa o islámica, aumento «estrechamente relacionado con la formación de una identidad musulmana en al-Andalus y también con procesos de legitimación política» ${ }^{25}$. La promoción de esta identidad formaba parte de la política omeya y nada menos que el califa al-Hakam II promulgó una orden para que aquellos cuyo nasab se hubiera olvidado lo recuperaran con la ayuda de genealogistas y lo inscribieran en registros al efecto. Antes, el cadí de Córdoba Mundir b. Sa'īd emitió una fetua que abría la mano para la adopción de la nisba al-Anșārī, argumentando que todo el que ayuda al Profeta, en la época que sea, lo es. La noticia la recoge Fierro en el mencionado artículo, en un texto de Ibn Dihya que traduce y que dice: «Si estando en al-Andalus oyes que alguien tiene el nasab Anșārī, no lo tomes en consideración atribuyéndole una verdadera genealogía».

Y según un texto de Ibn Hazm, traducido por Terés, «Los descendientes de los Anșār son numerosísimos en al-Andalus. Dice Ibn Sa 'īd: lo curioso es que este linaje falta en Medina [su país de origen] y sin embargo, en la mayor parte de las ciudades de al-Andalus lo encuentras en número insólito; un individuo me contó que preguntó por esta nisba en Medina y no encontró en ella más que un anciano y una anciana de los Aws» 26.

El auge de esta nisba continuó hasta la Granada nazarí, donde, según Ibn al-Jațīb «el apellido Anșārí era uno de los más extendidos del reino, perdurando también a su lado las nisbas Awsí y Jazraŷí» ${ }^{27}$.

Banū Manzūur al-Qaysī”, en Familias andalusies, EOBA, V, 23-37. Un fenómeno similar ocurre en otras familias como los Banū Hassūn, los Banū Simāk y otras recogidas por El Hour, R., "La transición entre las épocas almorávide y almohade a través de las familias de ulemas", en Biografías Almohades, I, EOBA, IX, 1999, 261-305.

${ }_{25}$ Fierro, M., "La nisba al-Anșārī en al-Andalus y el cadí Mundir b. Sa“īd", Al-Qantara, XXV, 1 (2004), 233-237; idem, "The Anșārīs, Nāṣir al-dīn, and the Naṣrids in al-Andalus", JSAI, 31 (2006), 232-247.

${ }^{26}$ Terés, E., 'Linajes árabes en al-Andalus, según la 'Ŷamhara' de Ibn Hazm (conclusión)", Al-Andalus, XXII, 2 (1957), 339.

27 Terés, "Linajes árabes", 340.

Al-Qanțara (AQ) XXX 2, julio-diciembre 2009, pp. 361-401 ISSN 0211-3589 
Hasta los sultanes nazaríes, en su intento por legitimar su califato, se llaman anșāríes de Jazraŷ y remontan su genealogía a $\mathrm{Sa}^{\text {‘d }} \mathrm{b}$. 'Ubāda ${ }^{28}$.

Dado que la adopción de esta nisba fue algo más o menos extendido en al-Andalus y, como ya se ha dicho, ante la notoria carencia de antepasados, podemos suponer que también estas tres familias se unieron a la práctica de fabricar de un rancio abolengo islámico. Pero, aun admitiendo que lo hicieran, se plantean más interrogantes.

¿Son las tres familias las que adoptan una nisba islámica? Se ha visto la política matrimonial de al-Šarrāt casando a sus hijas con dos familias anșāríes, una awsí y otra jazraŷí. Según Fierro, en algunos casos la nisba al-Anșārī va acompañada por la especificación al-Awsī o al-Jazraŷī en un intento de hacer la nisba al-Anșārī más convincente y menos sospechosa de reflejar el nasab wāsi ' permitido por el juez de 'Abd al-Rahmān III, Mundir b. Sa'īd. ¿Entraba dentro de la estrategia de alianzas de Ibn Gālib ennoblecer a su familia mediante estas uniones o planeó los matrimonios, como era habitual, por afinidad con sus discípulos/yernos, que adoptarían una nisba remontándose cada uno a una tribu, mientras él se asignaba la más amplia de al-Anșārī? La nisba, en el caso de los Banū 1-Ṭaylasān, sería adoptada no sólo por Muhammad, el marido de Fāṭima, sino también por su padre y el resto de la familia. Son sólo suposiciones que no pueden verse confirmadas por ahora, pero el caso aquí expuesto puede contribuir al estudio de esta nisba en al-Andalus.

\section{Estudios y transmisiones}

Estas tres familias no estuvieron unidas únicamente por lazos de parentesco, sino que además hubo entre ellas unas relaciones de transmisión de la ciencia que sin duda fueron debida a sus lazos familiares. Si repasamos las disciplinas que cultivaron, observamos una especial dedicación a las ciencias coránicas y filológicas, seguida por el interés por el hadiz, aunque alguno también cultiva el derecho o la poesía. Este interés por el Corán se inscribe dentro de la tónica general de la época, pues ya desde la etapa anterior de las taifas se observa un florecimiento de los estudios coránicos, que continúa en épocas almorá-

28 Rubiera Mata, M. aJ., “El califato nazarí”, Al-Qanțara, XXIX, 2 (2008), 293-305.

Al-Qanțara (AQ) XXX 2, julio-diciembre 2009, pp. 361-401 ISSN 0211-3589 
vide y almohade ${ }^{29}$. De los dieciséis o diecisiete ulemas cuya biografía se recoge aquí, al menos doce se dedicaron a la lectura coránica, dedicación que va unida al estudio de la lengua y la filología árabes. La unión de estas dos disciplinas no es algo extraño, pues el conocimiento de la lengua árabe era un requisito fundamental para un buen lector coránico. Está clara la dedicación al Corán de casi todos ellos, pero no sabemos si ejercieron como lectores coránicos oficiales en la mezquita. En algunos casos sólo se nos dice que aprendieron las lecturas coránicas o la salmodia, o incluso que eran almocríes, pero sin especificar un lugar, con lo cual es difícil averiguar hasta qué punto el estudio del Corán formaba parte de su formación o era una actividad. Ese estudio se expresa con frases como ajad da al-qirā'àt (n. ${ }^{\text {os }} 1,2,3,8$, 16), talä o talä bi-l-sab' (n.os 9, 10,11) o rawà 'an abi-hi... qirā'atan 'alay-hi bi-l-sab' (n. $\left.{ }^{\circ} 12\right)$. Otras veces se señala la importancia de algunos como almocríes y salmodiadores del Corán, como Abū 1-Qāsim Ibn al-Ṭaylasān (n. $\left.{ }^{\circ} 5\right)$, que compaginó esta actividad con su dedicación al hadiz (Wa-kāna ma'a ma 'rifati-hi li-l-qirā'āt wa-l- 'arabiyya mutaqaddiman fì șinā'at al-hadīt ) o como Abū Bakr Gālib Ibn al-Šarrāt (n. $\left.{ }^{\circ} 10\right)$ que, además de almocrí y tradicionista, destacó como gramático. De él se señala que poseía una hermosa voz tanto en la recitación coránica como en el hadiz, virtud destacable en la salmodia coránica. Se preocuparon por la ortología coránica también los números 3 (min ahl al-'ilm bi-taŷwìd al-qur'ān al-'azìm) y 8 (ra's fì taŷwìdi-hā wa-itqāni-hā). En ocasiones esta actividad es muestra de la vida ascética del biografiado, como ocurre en el caso de Sulaymān Ibn al-Ṭaylasān (n. ${ }^{\circ}$ ), que pasaba día y noche recitando el Corán - era raro encontrarlo sin que lo hiciera - y además ayunaba y pasaba las noches en vela (qawwām) ${ }^{30}$. Poco sabemos de Muhammad b. 'Ayyāš (n. $\left.{ }^{\circ} 14\right)$, pero el hecho de que aparezca en un repertorio de qurrā' indica su condición de almocrí.

${ }^{29}$ Marín, "La actividad intelectual”, 505 y ss. Un estudio realizado por Zanón sobre la obra de al-Dahabī Ma 'rifat al-qurrā' muestra el incremento de almocríes andalusíes fallecidos en estas épocas, que llega al máximo entre los años 551-600, superando en este intervalo al resto del mundo islámico. V. Zanón Bayón, J., "La actividad intelectual", en M. ${ }^{\mathrm{a} J}$. Viguera Molins (coord.), "El retroceso territorial de al-Andalus", Historia de España Menéndez Pidal, VIII, Madrid, 1997, 555-56.

${ }^{30}$ Se pueden encontrar ejemplos de recitación coránica continua y otras prácticas ascéticas en Marín, M., "Zuhhäd de al-Andalus (300/912-420/1029)", Al-Qanțara, XII, 2 (1991), 446-47. 
En cuanto al lugar en que ejercían la enseñanza o la recitación coránica, se especifica en pocas ocasiones la mezquita en la que lo hacían. En el caso de Abū l-Qāsim al-Šarrāt (n. ${ }^{\circ}$ 8) fueron las mezquitas aljama y la de Umm Mu'āwiya ${ }^{31}$; de su hijo Gālib (n. $\left.{ }^{\circ} 10\right)$ se dice que enseñaba en el maŷlis de su padre ya en vida de éste y después, por lo que podemos suponer que lo hacía en la mezquita de Umm Mu'āwiya; los dos Muhammad, yernos de Abū l-Qāsim (n.os 4 y 13), fueron almocríes de la mezquita aljama de Córdoba.

Casi se podría decir que estas tres familias acaparan la lectura coránica en Córdoba durante la etapa almohade, pero para ello habría que disponer de una relación de almocríes de esa época. J. Zanón ha elaborado una lista basada en la Takmila de Ibn al-Abbār de veintiún miembros, entre los que incluye a cuatro de los aquí mencionados, un buen porcentaje ${ }^{32}$. No están todos, pero lo mismo ocurrirá con los ajenos a éstos.

Fueron pocos los que se dedicaron con más intensidad a otras materias o actividades. El mundo del derecho atrajo a algunos de ellos, como Aḥmad Ibn al-Ṭaylasān (n. $\left.{ }^{\circ} 2\right)$, que se interesó en la redacción de contratos ('uniya bi- 'iqd al-šurüt) y fue experto en partición de herencias (farā'iḍ). Parece como si él y su hermano al-Qāsim se hubieran repartido las diferentes ramas del saber. También se ocupó de estas materias Muḥammad b. Aḥmad b. 'Ayyāš (n. $\left.{ }^{\circ} 13\right)$, que tal vez sea el que cultivó mayor número de disciplinas (lectura coránica, hadiz, lengua árabe y lexicografía, fiqh, gramática, farā'iḍ, hisāab). Como es lógico, otro dedicado al fiqh fue el único cadí de todos ellos, Muhammad b. Muhammad b. 'Ayyāš (n.os 15 y 16).

La poesía apenas si está representada en los conocimientos de estos individuos. Hubo entre ellos un poeta, 'Abd Allāh b. Muḥammad al-Šarrāt (n. ${ }^{\circ}$ 7), de cuya abundante poesía nos ha conservado un fragmento Ibn al-Jațīb ${ }^{33}$. El hăafiz Sulaymān Ibn al-Ṭaylasān conocía de memoria no sólo el Corán y otras obras, sino también poesías. También Abū l-Qāsim al-Šarrāṭ (n. ${ }^{\circ}$ 8) compuso poemas de tema ascético y era un excelente recitador de poesía.

${ }^{31}$ No se conoce la ubicación de esta mezquita. V. Zanón Bayón, J., Topografía de Córdoba almohade a través de las fuentes árabes, Madrid, 1989, 104.

${ }^{32}$ V. Zanón Bayón, J., La vida intelectual en al-Andalus durante la época almohade. Estudio de la Takmila de Ibn al-Abbār, Madrid, Universidad Complutense, 1991 (Tesis doctoral inédita), 77-80.

${ }^{33}$ Ibn al-Jațîb, al-Iḥạta fì ajbār Garnātạ, M.'A. 'Inān (ed.), El Cairo, 1973-78, III, 442.

Al-Qanțara (AQ) XXX 2, julio-diciembre 2009, pp. 361-401 ISSN 0211-3589 
Otro aspecto que destaca en los estudios de estos ulemas es la transmisión de otros familiares. En el apéndice biográfico se recogen todos aquellos de los que cada uno transmitió. Para no repetir aquí y a fin de que estas relaciones queden más claras, he elaborado un cuadro (v. anexo) en el que se puede apreciar la red de transmisión de conocimientos que se establece entre los distintos miembros de estas tres familias. Se aprecia con claridad que hay una rama de los Banū 'Ayyāš desligada de esta trama. En la primera generación vemos que Abū Ŷa'far Ahmad (n. $\left.{ }^{\circ} 3\right)$ transmite a sus tres hijos, hecho bastante frecuente, y que Ibn al-Šarrāt (n. ${ }^{\circ}$ 8) lo hace a todos los de la siguiente generación, hijos, yernos y sobrinos exceptuando uno, y que transmite también a su consuegro. Transmite además directamente a los miembros de la tercera generación. En la segunda generación destaca como transmisor su hijo Gālib (n. $\left.{ }^{\circ} 10\right)$ y en la tercera hay tres figuras señaladas, aunque el que recibe mayor número de transmisiones es Abū l-Qāsim Ibn al-Ṭaylasān (n. ${ }^{\circ}$ 5). Es la generación que se ha visto obligada a marcharse de Córdoba y que parece que, salvo los Banū 'Ayyāš, se extingue. Serán por tanto éstos los depositarios de todo el saber anterior.

¿Qué se transmiten unos a otros? Principalmente hadiz y lectura coránica, que también aprenden con otros maestros, aunque el traspaso de lo recibido de un maestro ajeno a la familia sólo se concreta en un caso: Abū Ŷa 'far Aḥmad Ibn al-Ṭaylasān (n. $\left.{ }^{\circ} 3\right)$ transmitió de Jalaf b. Yūsuf Ibn al-Abraš, se supone que lengua árabe (al-'arabiyya), a su hijo 'Abd Allāh (n. ${ }^{\circ}$ 1), que él a su vez transmitió a su sobrino Abū 1-Qāsim.

Llama la atención que ninguno de estos individuos viajara a Oriente para completar su formación. No es por falta de interés en aprender de los maestros orientales, pues Abū 1-Qāsim Ibn al-Ṭaylasān (n. ${ }^{\circ}$ 5) recibió por escrito la licencia enviada por muchos de ellos, a los que no conoció personalmente.

\section{Cargos y otras actividades}

No se puede decir que el de almocrí fuera un cargo y ni siquiera se sabe si estaba remunerado. Marín recoge un caso de almocrí a quien se retribuye a través de legados píos ${ }^{34}$. En el caso de estos ulemas, no

${ }^{34}$ Se trata de Faraŷ b. Hadīda y esto ocurre en la época de las taifas. Cf. Marín, "La actividad intelectual", 507-508.

Al-Qanțara (AQ) XXX 2, julio-diciembre 2009, pp. 361-401 ISSN 0211-3589 
hay ninguna información al respecto. Lo que sí se aprecia en algunas ocasiones es la unión de esta función con la de encargado del sermón (juțba) o de la oración (salā). Así ocurre en el caso de Muhammad b. Aḥmad b. Jalaf b. 'Ayyāšs (n. $\left.{ }^{\circ} 13\right)$, que fue șāhib al-ṣalā en la mezquita mayor de Córdoba, dirigiendo la oración preceptiva alrededor de treinta años. Su hijo 'Ayyāš (n. $\left.{ }^{\circ} 12\right)$ regentó la jațāba y fue imán en la aljama de Córdoba durante un tiempo, posiblemente hasta la conquista cristiana de la ciudad, pues de él se dice que fue el último jațīb de la aljama de Córdoba. Después debió de trasladarse a Málaga, donde nos consta que falleció. Por los mismos motivos se instaló en Málaga Abū l-Qāsim Ibn al-Ṭaylasān y allí fue jaṭỉb y se encargó de la oración en la aljama de la alcazaba. Estos cargos sí parece que estaban retribuidos, como puede deducirse del hecho de que Muhammad b. Muhammad b. 'Ayyāš (n. $\left.{ }^{\circ} 15\right)$ renunciara a ser remunerado.

Solamente él, nacido en Málaga, fue nombrado cadí de Granada en época de Yūsuf I, cargo que compatibilizó con el de encargado de la jutba de los viernes en la mezquita de la Alhambra. No obstante, no duró mucho en el puesto, pues a los tres días dimitió. Acabó compatibilizando la juțba y la salā en Málaga.

El tạlib de Málaga Abū Muhammad al-Šarrāt (n. $\left.{ }^{0} 7\right)$ parece ser el único que se aparta de la tónica familiar. Era kātib y se dice que prestaba sus servicios como redactor de escritos en la puerta del sultán, actividad ésta que se supone retribuida de alguna forma.

A los demás no se les conoce ocupación, aparte de su dedicación al estudio y a la enseñanza.

\section{Conclusiones}

Nos encontramos ante tres familias de ulemas, con bastantes miembros documentados en los repertorios biográficos, que viven en la Córdoba almohade y que al final de esta época, tras la conquista cristiana de Córdoba, acabarán trasladándose a Málaga y posteriormente a Granada. Es éste el único dato sobre la situación política de la época que existe en las fuentes que se ocupan de las biografias de estos individuos.

Las tres familias son anșāríes, aunque lo más probable es que su nisba fuera adoptada con el fin de ennoblecer su linaje. Serían el paradigma de una práctica establecida en al-Andalus desde la época omeya. Se ha señalado que las noticias sobre estas familias surgen en el 
siglo VI/XII, sin que existan biografías o datos de sus antepasados, hecho que podría deberse bien a que éstos no se dedicaron a la ciencia anteriormente, bien a una tardía conversión al islam e integración en las estructuras de la sociedad andalusí. Este hecho se detecta en otras familias y convendría hacer un estudio de las de esta época para poder llegar a una conclusión sobre la adopción de nisbas islámicas ${ }^{35}$.

Existe entre ellas una relación de parentesco, establecida por medio del matrimonio de dos hijas de Abū 1-Qāsim b. Gālib al-Šarrāt con dos de sus discípulos, Muhammad Ibn al-Ṭaylasān y Muhammad Ibn 'Ayyāšs. Esta relación de parentesco va unida a unas relaciones de transmisión del conocimiento entre los distintos miembros de la familia, estableciéndose una red que podríamos resumir en que todas las transmisiones familiares parten de Abū 1-Qāsim b. Gālib al-Šarrāt y todas confluyen en Abū 1-Qāsim Ibn al-Ṭaylasān. Todas ellas las heredará el cadí granadino Ibn 'Ayyāš, penúltimo descendiente conocido de estas tres familias.

La mayoría de estos ulemas cultivaron el hadiz y fueron almocríes, que además se ocuparon de la juṭba y de la salāa. Se podría establecer, pues, una cierta relación entre el desempeño de estos cargos, que muchas veces ostentaba también el cadí, y la actividad de la lectura coránica.

\section{Apéndice biográfico}

\section{Banū l-Ṭaylasān}

1) 'Abd Allāh b. Aḥmad b. Muḥammad b. Sulaymān b. Muḥammad b. Sulaymān al-Anșārī al-Awsì, conocido por Ibn al-Ṭaylasān, Abū Muhammad ${ }^{36}$.

35 El trabajo realizado por R. El Hour para la transición entre las épocas almorávide y almohade puede servir de base, ya que el autor se ha centrado en otros aspectos y no profundiza en este tema. Al mismo tiempo sería interesante el estudio de estas nisbas a lo largo del tiempo. En el plazo de dos años espero que esté establecida la identidad de todos los ulemas que aparecen en los repertorios biográficos andalusíes en la base de datos "Prosopografía de los ulemas de al-Andalus", en la que trabajo en la actualidad. Ello facilitará la reconstrucción y estudio de las familias de esta época y, sobre todo, posibles estudios diacrónicos sobre las nisbas tribales.

${ }^{36}$ Biografía en Ibn al-Abbār, al-Takmila li-Kitāb al-Ṣila, 'I. al-'A. al-Husaynī (ed.), El Cairo, 1955, 886, n. ${ }^{\circ} 2101$; ed. F. Codera, Madrid, 1887-1889, 509, n. ${ }^{\circ} 1437$.

Al-Qanțara (AQ) XXX 2, julio-diciembre 2009, pp. 361-401 ISSN 0211-3589 
Entre sus maestros se cita a su padre Abū Ŷa'far, a Abū l-Qāsim Ibn al Batūra (o Bațūza) y a Abū l-Qāsim al-Šarrāt (n. $\left.{ }^{o} 8\right)$. Con ellos estudió lectura coránica, lengua árabe y materias humanísticas, aprendiendo de memoria al-Šihāb de al-Quḍā'ī.

Se señala en su biografía que era tío paterno del transmisor Abū 1-Qāsim (n. ${ }^{0}$ 5).

Murió el miércoles 21 de $\mathrm{rabi}^{`} \mathrm{I}$ del 614/28 junio 1217 y fue enterrado la tarde del jueves en el cementerio de Umm Salama junto a sus antepasados.

2) Aḥmad b. Abī 'Abd Allāh Muḥammad b. Aḥmad b. Muḥammad b. Sulaymān b. Muhammad b. Sulaymān al-Anșārī al-Awsī, Abū $\hat{\text { Ya }}$ 'far, Ibn al-Ṭaylasān ${ }^{37}$.

Hermano del tradicionista Abū 1-Qāsim, al-Marrākuš̄i subraya su pertenencia a una familia ilustre dedicada a la ciencia. También refiere la anécdota ya mencionada sobre las causas del apodo familiar.

Transmitió de su abuelo materno Abū 1-Qāsim 'Abd al-Raḥmān b. Muḥammad al-Šarrāt, de su tío materno Abū Bakr Gālib y del pariente político (sihr) de ambos Abū 'Abd Allāh Aḥmad b. 'Ayyāš. Otros maestros fueron Abū Ŷa'far Ibn Muhammad b. Yahyà, Abū 1-'Abbās Ibn Salama ${ }^{38}$, Abū 1-'Abbās Yahyà al-Maŷrītīi ${ }^{39}$, Abū 1-Qāsim Aḥmad b. Yazīd b. Baqī ${ }^{40}$, Abū Muḥammad Ibn Sulaymān b. Hawt

37 Biografía en Takmila, ed. al-Husaynī, 120, n. ${ }^{\circ} 302$; ed. A. Bel y M. Ben Cheneb, Alger, 1920, 141, n. ${ }^{\circ} 302$; Dayl, I (i), 382-3, n. ${ }^{\circ} 532$.

38 Quizá se trate de Ahmad b. Salama b. Ahmad b. Yūsuf b. Salama (m. 598/1201-02), conocido por Ibn al-Sayqal, natural de Lorca, aunque creció en Valencia. Vivió en Tremecén y se trasladó temporalmente a Marrakech, requerido por el califa almohade Abū Yūsuf al-Manșūr b. Abī Ya qūb para que enseñara allí hadiz. En su biografía se cita como discípulos a Abū Ŷa'far Ibn al-Taylasān, que debe de ser éste, y a Abū l-Qāsim al-Qāsim, su hermano. Sin embargo, la fecha de su muerte me parece tardía para haber sido maestro del biografiado. Cf. Penelas, M., y Zanón Bayón, J., "Nómina de ulemas andalusíes de época almohade", en EOBA, IX, Madrid-Granada, 1999, 11-222, n. ${ }^{\circ} 175$.

39 Aunque el nombre aparece incompleto en Dayl, debe de ser el cadí de Granada Yahyà b. 'Abd al-Raḥmān b. 'İsà b. 'Abd al-Rahmān Ibn al-Haŷŷ (519-598/1125-1201). Cf. Penelas y Zanón, "Nómina de ulemas", n. ${ }^{\circ} 2391$.

${ }^{40} \mathrm{~V}$. la biografía de este descendiente de Baqī b. Majlad, llamado Ahmad b. Yazīd b. 'Abd al-Raḥmān en Takmila, ed. al-Husaynī, n. ${ }^{\circ}$ 292; ed. Bel y Ben Cheneb, n. ${ }^{\circ} 292$; al-Dahabī, Siyar a 'lām al-nubalā', Beirut, XXII, 274-7, n. ${ }^{\circ}$ 156; al-Șafadī, Kitāb al-wāfí, VIII, 3697; al-Suyūtī, Bugyat al-wu'ā, I, 399, n. ${ }^{\circ}$ 789; Ahmad Bābā, Nayl al-ibtihā̂y bi-tatrīz al-Dībāŷ, ed. al margen de Ibn Farhūn, al-Dībā̂y al-mudhab, Beirut [19-?], 63; Majlūf, M., Šaŷarat al-nūr al-zakiyya fì tabaqāt al-mālikiyya, El Cairo, 1950-52, I, 178, n. ${ }^{\circ}$ 578; al-Dahabī, Kitāb al-Mu'ìn fì țabaqāt al-muhaddițīn, H.'A.R. Sa'īd (ed.), 
Allāh ${ }^{41}$, Abū Muhammad 'Abd al-Haqq al-Jazraŷī ${ }^{42}$. De al-Andalus le dieron licencia para transmitir (iŷāza) Abū Ŷa'far Ibn Šarāhīil ${ }^{43}$, Abū 1-Jatțāb Ahmad b. Muhammad b. Wāŷib ${ }^{44}$, Abū Darr Muṣ'ab b. Abī Rakab ${ }^{45}$, Abū 'Abd Allāh Ibn Ayyūb b. Nūḥ ${ }^{46}$, Abū 1-Qāsim Aḥmad b. 'Abd al-Wadūd b. Samaŷūn ${ }^{47}$ y Abū Muhammad 'Abd al-Mun'im Ibn al-Faras ${ }^{48}$. De Oriente le concedió îyazza un grupo numeroso que compartió con su hermano el transmisor (rāwiya) Abū 1-Qāsim al-Qāsim, entre los que se cuentan Abū 1-Hasan Ibn al-Mufaḍ̣al al-Maqdisī, Ibn Hibat Allāh Ibn Salāma al-Š̉afi'‘̄i, Fajr al-Dīn Abū 'Abd Allāh Muhammad b. Ibrāhīm al-Fārisī al-Habarī? (o al-Jabarī) y Ŷamāl al-Dīn Abū 1-Qāsim Hamza b. 'Alī b. Ganām (o 'Uțmān) al-Majzūmī.

Él se interesó en la redacción de contratos ( 'uniya bi- 'iqd al-šurūt) y fue experto en derecho sucesorio ( $\operatorname{far} \bar{a}$ 'id $)$.

Cordobés, salió de su lugar tras la conquista cristiana el domingo a siete por pasar de šawwāl del 633/29 junio 1236 y vivió en Málaga, trasladándose posteriormente a Granada, donde se estableció. Allí, dice Ibn al-Abbār que alguno de sus discípulos estudió con él.

Había nacido en ramaḍān de 570/1175 y murió en Elvira alrededor del 650/1252-53.

3) Aḥmad b. Muḥammad b. Sulaymān b. Muḥammad b. Sulaymān al-Anșārī al-Awsīe Abū Ŷa'far, conocido por İbn al-Ṭaylasān y por Ibn Sulaymān ${ }^{49}$.

Natural de Córdoba, creció en Sevilla.

Amman, 1404/1984, 192, n. ${ }^{o}$ 2039; Kaḥ̣āla, Mu 'ŷam al-mu'allifìn. Tarāŷim muṣannifí l-kutub al- 'arabiyya, Damasco, 1957-61, II, 206; Bābā, Nayl al-ibtihâŷ, 221.

41 Sobre este cadí, véase Marín, M., "Ibn Hawt Allāh (612/1215) y dos mujeres de Sevilla", Al-Qanțara XXIX, 1 (2008), 209-219, y Penelas y Zanón, "Nómina de ulemas", n. ${ }^{\circ} 910$.

${ }^{42}$ Se trata sin duda del experto en qirā'āt 'Abd al-Haqq b. Muhammad b. 'Abd al-Haqq (526-604). Cf. Penelas y Zanón, "Nómina de ulemas", n. ${ }^{\circ} 716$.

43 Debe de ser Ahmad b. 'Abd Allāh b. Ahmad b. 'Abd al-Malik (522-606). Ibidem, n. ${ }^{\circ} 206$.

${ }^{44}$ Cadí de Játiva y de Valencia que vivió entre 537/1142 y 614/1217. Ibid., n. ${ }^{\circ} 382$.

${ }^{45}$ Cf. Penelas y Zanón, "Nómina de ulemas", n. ${ }^{\circ} 2298$.

46 Ibidem, n. ${ }^{\circ} 1779$.

47 Ibid., n. ${ }^{\circ} 234$.

${ }^{48}$ Ibid., n. ${ }^{\circ} 1073$.

49 Biografía en Takmila, ed. al-Husaynī, 81, n. ${ }^{\circ} 213$; ed. Bel y Ben Cheneb, 99-100, n. ${ }^{\circ}$ 213; Dayl, I (2), 432-3, n. ${ }^{\circ}$ 643; Dahabī, Ta'rïj al-Islām, IL (años 571-580), 276, n. ${ }^{\circ} 297$.

Al-Qanțara (AQ) XXX 2, julio-diciembre 2009, pp. 361-401 ISSN 0211-3589 
Ya se ha indicado que el laqab de Ibn al-Taylasān se lo puso su maestro Jalaf $b$. Yūsuf Ibn al-Abraš, con quien estudió en Sevilla la lengua árabe (al- 'arabiyya), debido a su diario cambio de indumentaria. La anécdota la recoge Ibn al-Abbār en la Takmila, mientras que Ibn 'Abd al-Malik remite a la biografía de su nieto Abū Ŷa‘far Aḥmad para la explicación ${ }^{50}$.

Entre los maestros cuyas lecciones escuchó Ahmad se cita a Abū Marwān Ibn Masarra, Ibn Baškuwāl, Abū Muḥammad b. Mugīt y a su consuegro (sihrr) Abū 1-Qāsim 'Abd al-Rahmān al-Šarrāt. También tomó las lecturas coránicas (talā bi-l-sab) de Abū 1-Hasan Šurayh.

De él transmitió su hijo Abū 'Abd Allāh las enseñanzas de Ibn al-Abraš, que él a su vez transmitió a su sobrino Abū l-Qāsim, y también su otro hijo Abū Muhammad. Al-Marrākušī dice: «Ibn al-Zubayr menciona la riwāya de él de su hijo Abū l-Qāsim Sulaymān, pero no recuerdo ahora a Sulaymān entre los hijos. Dios sabe si ha omitido un Ibn entre Abū l-Qāsim y Sulaymān, aunque tampoco conozco entre sus hijos a ninguno de esa kunya». Por ello opina que debe corregirse la información de Ibn al-Zubayr. Sin embargo, la corrección propuesta no parece pertinente, ya que se encuentran documentados los tres hijos: 'Abd Allāh, Muhammad y Sulaymān.

Destacó por su perfecta pronunciación (taŷwìd) y recitación coránica (tilāwa).

Murió a edad elevada en Córdoba y fue enterrado el 8 de șafar de 579/2 junio 1183 .

4) Muhammad b. Aḥmad b. Muhammad b. Sulaymān b. Muhammad b. Sulaymān al-Anșārī al-Awsīe conocido por Ibn al-Ṭaylasān y por Ibn Sulaymān, Abū 'Abd Allāh ${ }^{51}$.

Dice Ibn 'Abd al-Malik que pertenecía a una familia sabia y virtuosa, dedicada a la tradición y bendecida con riquezas que empleaba al servicio de Dios. Él, por su parte, es calificado de persona de buen carácter, generoso con sus hermanos y modesto.

Aunque en su biografía no se dice, se casó con Umm al-Fath Fāțima bint Abī l-Qāsim 'Abd al-Raḥmān b. Muḥammad b. Gālib al-Qurțubī al-Šarrāṭ (n. $\left.{ }^{\circ} 8\right)$.

${ }^{50}$ Dayl, I (1), 382.

51 Biografía en Takmila, ed. al-Husaynī, 533, n. ${ }^{\circ}$ 1450; ed. Codera, n. ${ }^{\circ} 806 ;$ Dayl, VI, 40, n. $^{\circ} 83$.

Al-Qanțara (AQ) XXX 2, julio-diciembre 2009, pp. 361-401 ISSN 0211-3589 
Estudió con su padre Aḥmad y con su suegro (șihr) Abū l-Qāsim Ibn Gālib y otros.

Natural de Córdoba, nació en el año 537/1142-43 y murió en șafar del 581/mayo 1185. Le rezó la oración fúnebre su suegro, Abū 1-Qāsim Ibn Gālib. Fue enterrado en el cementerio de Umm Salama junto a la tumba de su padre.

En el Dayl se recoge el siguiente relato de su hermano 'Abd Allāh:

dos o tres días después de la muerte de mi hermano Abū 'Abd Allāh vino a verme un hombre piadoso, conocido por Ibn Baliya y me dijo: «la noche de la muerte de tu hermano Abū 'Abd Allāh vi en sueños a un hombre que me decía: "mañana si Dios quiere, asistirás al entierro de un hombre piadoso digno del paraíso, que será enterrado en el cementerio de Umm Salama”. Cuando me desperté y recé la oración de la mañana, me dirigí al cementerio de Umm Salama y allí pasé todo el día viendo a quién enterraban. Después de la oración del 'aṣr, tuvo lugar el entierro de tu hermano Abū 'Abd Allāh y, por Dios, que no se enterró allí aquel día a nadie como él. He venido para que sepas que está en el paraíso».

Este tipo de sueños sobre el paraíso aparece con cierta frecuencia en los repertorios biográficos. Se refieren de personas de vida ascética o con experiencias místicas y el aparecido puede ser un asceta o alguien ya fallecido, renombrado por su piedad; en ocasiones se trata de Mālik o el epónimo de otra escuela. En este sueño en concreto se funden dos temas: el de la vida futura en el paraíso y la aparición de alguien que impele al que sueña a ir a algún sitio al encuentro de otra persona. M. Marín ha recogido y clasificado los sueños en los repertorios andalusíes en un trabajo sobre los ascetas de al-Andalus en el siglo IV/X ${ }^{52}$.

Las noticias sobre él proceden de su hijo Abū 1-Qāsim.

5) Al-Qāsim b. Muḥammad b. Aḥmad b. Muḥammad b. Sulaymān b. Muḥammad b. Sulaymān al-Anșārī al-Awsī, Abū l-Qāsim Ibn al-Ṭaylasān al-Ŷamal (el camello) al-Qurțubī ${ }^{53}$.

52 Marín, M., "Zuhhād de al-Andalus", Al-Qanțara, XII, 2 (1991), 439-468.

53 Biografía en al-Ru'aynī, Barnāmaŷ šuyūj al-Ru'aynī, I. Šabūh (ed.), Damasco, 1962, 27-30; Ibn al-Abbār, Takmila, ed. Codera, 703-4, n. ${ }^{\circ}$ 1976; Dayl, V (2), 557-66, n. ${ }^{\circ}$ 1090; Ibn al-Zubayr, Silat al-Sila, 'A.S. al-Harrās y S. A'rāb (eds.) [Rabat], 1994, IV, 194-95, n. ' 383; al-Dahabī, K. al-Mu' ìn, 201, n.' 2126; idem, Tadkirat al-huffäz, Hyderabad, 1388-1390/1968-1970, IV, 1426-28, n. ${ }^{\circ} 1139$; idem, Siyar, XXIII, 114-5, n. ${ }^{\circ} 87$; idem, Ta'rīj al-Islām, XLVII, 135-6, n. ${ }^{\circ}$ 116; Ibn al-Ŷazarī, Gāyat al-nihāya, II, 23, n. ${ }^{\circ}$ 2601; al-Suyūtị, Bugyat al-wu'āa, II, 261, n. ${ }^{\circ}$ 1931; Bābā, Nayl, 221; Bagdādī, I.B., Hadiyyat al-'ārifîn, asmā' al-mu'allifiñ wa-ātāâr al-mușannifin min Kašf al-zunūn, Beirut, 1413/[1992] (facsímil Estambul, 1951), V, 829; Majlūf, Šaŷarat al-nūr, I, 182, n. ${ }^{\circ}$ 596; Kaḥhâla, Mu'yam, VIII, 113-114 y 122; Pons Boigues, F., Ensayo bio-bibliográfico sobre

Al-Qanțara (AQ) XXX 2, julio-diciembre 2009, pp. 361-401 ISSN 0211-3589 
Hijo de Abū 'Abd Allāh Muhammad (n. $\left.{ }^{\circ} 4\right)$ y de Fātima bint 'Abd al-Raḥmān b. Muhammad b. Gằlib al-Šarrāt (n. ${ }^{\circ}$ 9), es él el miembro más destacado de los Banū 1-Ṭaylasān y, junto con su hermano Ahmad, representa la unión de este linaje con el de los Banū Gālib al-Š̉arrāt. Debió de tener una hija que se unió en matrimonio con Abū 'Abd Allāh Muhammad Ibn 'Ayyāš, de quien se dice que era șihr suyo.

Transmitió de su abuelo materno al-Qāsim b. Gālib al-Šrarrāt (n. $\left.{ }^{\circ} 8\right)$, no se sabe si directamente o a través de su madre, Umm al-Fatḥ Fātima bint Abī l-Qāsim al-Šarrāṭ (n. ${ }^{\circ}$ 8). También transmitió de su tío materno Gālib (n. $\left.{ }^{\circ} 10\right)$ y de su tío paterno Abū Muḥammad 'Abd Allāh (n. $\left.{ }^{\circ} 1\right)$. Ciñéndonos al ámbito familiar hay que destacar al almocrí Abū 'Abd Allāh Muḥammad b. Aḥmad b. Jalaf b. 'Ayyāš al-Jazraŷī (n. $\left.{ }^{\circ} 13\right)$, con quien estudió al-Idgām al-Kabìr y la qirā'a de Ya'qūb que no llegó a completar, con transmisión de su abuelo Abū l-Qāsim Ibn Gālib (n. ${ }^{\circ}$ 8) y de Abū Isḥāq Ibrāhīm b. 'Abd al-Malik b. Ṭalḥa ${ }^{54}$. Con este Ibn 'Ayyāš leyó también el Kitāb al-Hādī de Ibn Sufyān, transmitido del mencionado Ibn Talha. Omito los nombres de otros maestros, debido a la extensión de la relación de sabios citados en al-Dayl wa-l-takmila por Ibn 'Abd al-Malik al-Marrākušī, quien dice que sus maestros pasaron de doscientos. Entre ellos hay ulemas de Córdoba, Sevilla, Málaga, Granada, Ceuta, Mișr y otras ciudades de Oriente. No quiere eso decir que Ibn al-Ṭaylasān visitara todas esas ciudades, pues no los conoció a todos, sino que algunos de los incluidos en esa lista le concedieron $i y \hat{a} z a$ por escrito sin que mediara una audición presencial.

Precisamente una de las cosas que llama la atención de su biografía es que no se cite en ninguna fuente el posible viaje a Oriente para completar su formación, máxime cuando se dice que destacó tanto por su interés por el estudio como por la transmisión del conocimiento recibido. De hecho era una persona dedicada totalmente a la ciencia que no ejerció ninguna otra actividad. Respecto a las materias cul-

los historiadores y geográfos arábigo-españoles, Madrid, 1898, 286, n. ${ }^{\circ} 245$; Vizcaíno Plaza, J.M., "Lectores del Corán en al-Andalus: andalusíes en dos diccionarios biográficos de qurrä",", EOBA, 729-779, n. . 416; Marín, "Parentesco", 340-1; Lirola Delgado, J., y Puerta Vílchez, J.M. (eds.), Biblioteca de al-Andalus, 5, Almería, art. "Ibn al-Ṭaylasān". Este último artículo apareció con posterioridad a la entrega del presente trabajo, acompañado de un cuadro genealógico de las tres familias aquí estudiadas elaborado por J. Lirola que presenta mínimas diferencias con el que se ofrece aquí como anexo.

${ }^{54}$ Para la biografía de este almocrí, discípulo de Šurayh, cf. Penelas y Zanón, "Nómina de ulemas", n. ${ }^{\circ} 44$.

Al-Qanțara (AQ) XXX 2, julio-diciembre 2009, pp. 361-401 ISSN 0211-3589 
tivadas por este prestigioso almocrí, se dice que sobresalió tanto en hadiz como en lecturas coránicas y lengua árabe.

Respecto a las obras compuestas por él, se han conservado los siguientes títulos:

1. Kitāb fì ajbār al-sālihīn (o al-sulahāa') bi-l-Andalus (Noticias de los hombres virtuosos de al-Andalus), según Ibn al-Abbār, o al-Tabyīn 'an manāqib man 'urifa qabru-hu fi-Qurtuba min al-sahāba wa-l-tābi 'ìn wa-l-'ulamā' wa-l-sāliḥin, según Ibn 'Abd al-Malik ${ }^{55}$.

2. Un Mujtasar del anterior, en un fino cuaderno que Ibn 'Abd al-Malik encontró escrito con su letra.

3. Kitāb Bayān al-minan 'alà qāri' al-kitāb wa-l-sunan.

4. Bugyat al-waqqād fi l-ta 'rïf bi-simat al-ŷihād.

5. Kitāb al-wa'd wa-l-inŷāz fì l-'awālì (al-hadīt).

6. Kitāb mā warada min taglìz al-amr 'alà šarabat al-jamr.

7. Kitāb al-Ŷawāhir al-mufașalāt fì l-musalsalāt, también llamado por Ibn 'Abd al-Malik, quien dice haber visto el ejemplar escrito con la propia letra del autor, Kitāb al-Ŷawāhir al-mufașsalāt $f i$ tașnîf al-ahādìt al-musalsalāt.

8. Zaharāt al-basātīn wa-nafahạt al-riyāḥin fì garāìb ajbār almusnadīn wa-manāqib ātār al-muhtadīn, título que Ibn al-Abbār abrevia como Kitāb garā'ib ajbār al-musnadīn wa-manāqib ātār al-muhtadin. Esta obra contenía los nombres de la mayoría de sus maestros.

9. Iqtițāf al-anwār wa-ijtițāf al-azhār min basātīn al-'ulamā' al-abrār, resumen de la anterior.

Probablemente una de estas dos últimas fue la que sirvió de fuente a Ibn al-Abbār y a al-Marrākušī para gran número de biografías, aunque este último quizá las conociera a través de Abū 'Abd Allāh Ibn 'Ayyāš (n. $\left.{ }^{\circ} 14\right)^{56}$.

Este Ibn 'Ayyāš fue discípulo y yerno de Ibn al-Ṭaylasān. Otros discípulos fueron: al-Ru'aynī, que lo incluyó en el Barnāmaŷ sobre sus maestros; Abū Muhammad Ibn Hārūn al-Tāài que le oyó el Kitāb al-wa'd wa-l-inŷāz fì l- 'awālì (al-hadìt), en el transcurso del año 641/ 1243-4 en Málaga, recibiendo licencia del maestro para transmi-

\footnotetext{
55 Pons antepone a este título Ajbār al-qurțbiyyīn wa-, pero no se encuentra en las fuentes consultadas.

${ }^{56}$ Ibn al-Ṭaylasān aparece con cierta frecuencia como fuente en la Takmila y como tal es mencionado por Ibn al-Abbār en la introducción a la obra. V. ed. Husaynī, 7, y Bel, A. y Ben Cheneb, M., "La préface d'Ibn el-'Abbar a sa Takmila-t essila (texte arabe et traduction française)", Revue Africaine, 59 (1918), 307-335, esp. 316-17 y 325.
} 
tirlo ${ }^{57}$; Abū 'Abd Allāh Muḥammad b. Aḥmad b. 'Alī b. Bartāā, cadí de Málaga ${ }^{58}$, y Abū 1-Husayn b. 'Abd al-'Azīz b. Muhammad b. Abī 1-Ahwas ${ }^{59}$.

Nació en Córdoba en el año 575/1179-80 ó 576/1180-81 y allí vivió, exceptuando una estancia en Sevilla, hasta el año 633/1236, en que, debido a la conquista cristiana de Córdoba, se vio obligado a marchar a Málaga. En esta ciudad se instaló hasta su muerte y fue jațib y encargado de la oración en la aljama de la alcazaba.

Murió en el 642/1244-45.

6) Sulaymān b. Aḥmad b. Muḥammad b. Sulaymān b. Muhammad b. Sulaymān al-Anșārī al-Awsī, Abū 1-Qāsim, conocido por Ibn al-Ṭaylasān y llamado también al-Hāfiz, pues sabía de memoria el Corán y las tradiciones (sunan). ${ }^{60}$ No sólo conocía de memoria el hadiz, sino que también cultivaba literatura, historia, lexicografía y poesías.

Entre los maestros de los que transmitió se cita a los siguientes: Abū Bakr Ibn Samaŷūn ${ }^{61}$, Abū Bakr Muhammad b. Mūsà al-Qaŷāliŷī/al-Qašālišī ${ }^{62}$, Abū Jālid al-Qurašī, Abū Jālid Ibn Rifā'a 63, Abū 'Abd Allāh (Ibn 'Irāq) al-Baysānī 64, Abū Zayd al-Suhaylī ${ }^{65}$, Abū 1-Qāsim Ibn Baškuwāl, Abū 1-'Abbās Ibn Ṣālị al-Kafīf ${ }^{66}$, Abū 1-Qāsim al-Šarrāt (n. ${ }^{\circ}$ 8).

57 Sobre 'Abd Allāh b. Muhammad b. Hārūn v. Ibn al-Zubayr, Silat al-Ṣila, III, n. ${ }^{\circ}$ 250; Ibn Haŷar al-'Asqalānī', al-Durar al-kāmina fì a yān al-mi'a al-țāmina, M.S. Ŷādd al-Haqq (ed.), El Cairo [1966], II, 409 (2234); Ibn al-Qāḍī, Durrat al-ḥiŷăl fì asmā' al-rî̀ăl, M. Abū l-Nūr (ed.), El Cairo, 1390-1392/1970-1972, III, 44, n. ${ }^{\circ} 946$.

58 Calero Secall, M.a.'., "Dinastías de cadíes en la Málaga nazarí", Jábega: revista de la Diputación Provincial de Málaga (primer trimestre 1987), 12, nota 11; Ibn Ḥaŷar, al-Durar al-kämina, III, 428, n. ${ }^{\circ} 3417$.

${ }_{59}$ Calero Secall, "Dinastías", 12, nota 9.

${ }^{60}$ Biografía en Takmila, ed. Codera, n. ${ }^{\circ}$ 1989; Dayl, IV, 137; Ibn al-Zubayr, Silat al-Sila, IV, n. ${ }^{\circ} 408$.

${ }^{61}$ Existe un Abū Bakr Ibn Samaŷūn que vivió en época de al-Zāfir b. Dī 1-Nūn (409/1018), con el que no se puede identificar. Tal vez se trate de otro con una kunya distinta.

${ }^{62}$ M. 568/1172 ó 570/1174. Cf. su biografía en Takmila, ed. al-Husaynī, n. ${ }^{\circ}$ 1399; ed. Codera, n. ${ }^{\circ} 755$; al-Suyūtīi, Bugyat al-wu'à, I, 253, n. ${ }^{\circ} 466$.

63 Seguramente se trata de Yazīd b. Muhammad b. Yazīd b. Yahyà b. Muhammad b.

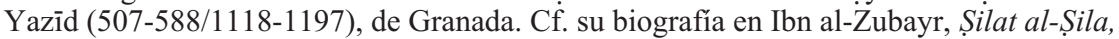
$\mathrm{V}, \mathrm{n}^{\circ} 605$.

${ }^{64}$ Es Muhammad b. Aḥmad b. Muhammad, Ibn 'Irāq, cuya nisba aparece también como al-Faysānī. Cf. Penelas y Zanón, "Nómina de ulemas", n. ${ }^{\circ} 1708$.

65 Puede ser 'Abd al-Rahmān b. "Abd Allāh b. Ahmad b. Abī 1-Hasan Aṣbag b. Husayn b. Sa'dūn. Cf. ibidem, n. ${ }^{\circ} 750$.

66 Se trata de Aḥmad b. Șālih al-Majzūmī al-Kafiff, m. 562/1166 ó 564/1168, natural de Córdoba y muerto en Fez. Cf́. ibid., n. ${ }^{\circ} 176$.

Al-Qanțara (AQ) XXX 2, julio-diciembre 2009, pp. 361-401 ISSN 0211-3589 
De él transmitieron Abū l-Qāsim al-Qāsim y Abū Ŷa'far Aḥmad, los dos hijos de su hermano Abū 'Abd Allāh Muḥammad. El primero de ellos dice haber leído con él, mientras servía en la aljama de Córdoba, $a l-G a r i \bar{b}$ y los $A m t \bar{a} l$ de Abū 'Ubayd, y alrededor de la cuarta parte de los Amālì de al-Qālī, obra que se sabía de memoria entera o casi entera.

En su biografía se encuentran algunos datos, comunes a otras biografías de $z u h h \bar{a} d$, que muestran que practicaba el ascetismo, como la recitación continua del Corán, incluso de noche, el ayuno y las velas nocturnas en constante oración. También encontramos otro tópico que se aplica a los ascetas como muestra de santidad, que es causar fenómenos paranormales. Así, su sobrino Abū 1-Qāsim Ibn al-Ṭaylasān, que es la fuente principal de su biografía, afirma que al enterrarlo presenció, a la entrada de la tumba, un resplandor como no había visto nunca ni vio después.

Nació en el año 543/1148-49 y murió el 10 de šawwāl del 608/16 marzo 1212, según Ibn 'Abd al-Malik, o la noche del jueves 29 de ramaḍān del año 607/16 marzo 1211, según Ibn al-Abbār. Esta diferencia en las fechas resulta extraña cuando ambos autores utilizaron a Ibn al-Ṭaylasān como fuente y también curiosa, por coincidir día y mes de las datas cristianas. Le rezó el imán de la oración preceptiva Abū 'Abd Allāh Ibn 'Ayyāš y fue enterrado en el centro del cementerio de Umm Salama.

\section{Banū Gālib al-šarrāt}

7) 'Abd Allāh b. Muḥammad al-Šarrāt, Abū Muhammad ${ }^{67}$.

Natural de Málaga, posiblemente sea descendiente de Abū 'Abd Allāh Muhammad (n. $\left.{ }^{\circ} 11\right)$, aunque no existen datos en las fuentes que permitan confirmarlo y su posición en el árbol genealógico es totalmente conjetural.

No se conoce la fecha de su nacimiento y la única referencia cronológica que nos proporciona su biógrafo Ibn al-Jatīi es que en el año 700/1300-1301 aún vivía. Añade que falleció en Granada, siendo kātib.

Aparte de estos traslados, seguramente forzados por el avance territorial cristiano, en su biografía se advierten otros cambios con respecto a las generaciones anteriores de su familia, los Banū 1-Šarrāt, y

${ }^{67}$ Biografía en Ihạtạa, III, 441-2.

Al-Qanțara (AQ) XXX 2, julio-diciembre 2009, pp. 361-401 ISSN 0211-3589 
de las otras dos familias ligadas a ellos. Fueron sus antepasados cultivadores de las ciencias religiosas en especial, si bien tocaron otras materias como la lengua, lexicografía, o gramática, probablemente como base para el estudio coránico. 'Abd Allāh sale del círculo familiar - es el único de su generación que no transmite de Abū 1-Qāsim al-Šarrāt - y quizá estudia con otros maestros, lo que le lleva a dedicarse a ciencias que podríamos denominar «profanas».

Se dice que era un tâlib ilustre, es decir, formaba parte del grupo de ulemas de los que se rodearon los califas almohades, con el fin de que difundieran la doctrina almohade. Sin embargo no lo recoge M. ${ }^{\text {a I. }}$ Calero Secall entre los talaba de Málaga. Tal vez porque cuando desaparece la institución de los talaba al servicio del poder él ya está en la Granada nazarí. Ibn al-Jatîib lo describe como:

\begin{abstract}
inteligente, sagaz, ingenioso y muy jactancioso, menospreciaba a quien no estaba a su altura; agudo en sus salidas, se entregaba sin freno a las gracietas. Poeta prolífico, se ocupó del $a d a b$ y la lengua árabe, destacó en el hisāa y los argumentos de sus cuestiones jurídicas. Se le pedían sus servicios como redactor de escritos en la puerta del sultán. Gozó del favor del heredero y se le confió el desempeño de altos cargos, de modo que hubiera prosperado y recogido grandes honores si no se hubiera demorado, pero sufrió el zarpazo del destino poco tiempo después de alcanzar el éxito. Entre él y el visir Abū 'Abd Allāh Ibn al-Hakīm existía un odio que sólo la muerte impidió que se concluyera en venganza.
\end{abstract}

No se sabe a qué heredero hace referencia Ibn al-Jatīb. Probablemente se esté refiriendo al reinado de Muhammad II (671-701/ 1273-1302) y el heredero sería el futuro Muhammad III, que accede al trono en 701/1302, época en la que debió de fallecer Abū Muhammad al-Šarrāt. Esto concordaría con las malas relaciones habidas entre él e Ibn al-Hakìm, que, aunque fue nombrado visir por Muhammad III, ya en época de su padre Muḥammad II se hallaba en la corte granadina ${ }^{68}$.

De su abundante producción poética sólo se han conservado unos versos en la Ihạta de Ibn al-Jațîb, que improvisó en un maŷlis con el visir Abū 'Abd Allāh Ibn 'Îsà en Málaga en presencia de un grupo de literatos.

68 Sobre el doblemente visir, v. Rubiera Mata, M. JJ., "El Du l-wizāratayn Ibn al-Hakīm de Ronda”, Al-Andalus, XXXIV, 1 (1969), 105-121.

Al-Qanțara (AQ) XXX 2, julio-diciembre 2009, pp. 361-401 ISSN 0211-3589 
8) 'Abd al-Raḥmān b. Muḥammad b. Gālib al-Anșārī, Abū 1-Qāsim, conocido por al-Šarrāt ${ }^{6}$.

De Córdoba.

Este almocrí cordobés es sin duda el miembro más importante de su familia, no sólo por su posición en los estudios coránicos, sino por su influencia en el resto de los aquí estudiados. Fue el artífice de la unión de estas tres familias, aunque nada de ello dicen sus biógrafos y hay que deducirlo de datos sueltos en las biografías de los demás.

Entre los maestros de los que tomó las lecturas coránicas se citan los siguientes: Abū l-Ḥasan ('Abd al-Rahīm b. Qāsim) al-Hị̂āāī 70, Abū l-Qāsim Ibn Riḍà ${ }^{71}$, Abū 1-'Abbās al-Zawzanālī ${ }^{72}$, Abū 1-Hasan Šurayḥ b. Muhammad ${ }^{73}$, Abū 'Abd Allāh Ibn Ma'mar y Abù Muhammad al-Šantarīnī al-Kafĩf. Transmitió también de Abū l-'Abbās Ibn Ta'bān, a quien le oyó el Taljịṣ de Abū Ma‘šar. Oyó el hadiz a Abū 1-Qāsim Ibn Baqī ${ }^{74}$, Abū 1-Hasan (Yūsuf) Ibn Mugị̂t ${ }^{75}$, Abū 'Abd Allāh Ibn Naŷŷāḥ ${ }^{76}$, Abū Bakr Ibn Ṭāhir ${ }^{77}$, Abū 'Abd Allāh (Ibn Ŷa‘far) Ibn Makkī, Abū Bakr Ibn al-'Arabī, Abū Marwān Ibn

${ }^{69}$ Biografía en Takmila, ed. Codera, 577, n. ${ }^{\circ}$ 1620; Ibn al-Zubayr, Silat al-Sila, III, 198, n. ${ }^{\circ}$ 340; Ibn al-Ŷazarī, Gāyat al-nihāya, I, 379, n. ${ }^{\circ}$ 1614; al-Gubrīn̄̄, 'Unwān al-dirāya fì man 'urifa min al- 'ulamā' fì l-mi'a al-sābi 'a bi-Biŷāya, R. Būnār (ed.), Alger, 1389/1970, 204; al-Dahabī, Tabaqāt al-qurrāo, II, 867, n. ${ }^{\circ}$ 821; Vizcaíno Plaza, "Lectores del Corán", n. ${ }^{\circ} 59$.

${ }^{70}$ Cf. Penelas y Zanón, "Nómina de ulemas", n. ${ }^{\circ} 814$.

${ }^{71}$ Quizá sea el almocrí y jațīb 'Abd al-Raḥmān b. Aḥmad b. Jalaf b. Riḍà (470-545). Ibidem, n. ${ }^{\circ} 728$.

${ }^{72}$ Se trata de Ahmad b. Hišām al-Ŷudāmī al-Muqri', cuya biografía es recogida en Takmila, ed. al-Husaynī, n. ${ }^{\circ}$ 133; ed. Bel y Ben Cheneb, n. ${ }^{\circ} 133$, y Dayl, I (2), 866.

${ }^{73}$ Sobre este almocrí y cadí sevillano, v. El Hour, "La transición", 301.

$74 \mathrm{~V}$. nota 40.

${ }^{75}$ Existen varios Abū l-Hasan Ibn Mugīt, pero por las fechas, sólo puede tratarse de Yūnus (no Yūsuf) b. Muhammad b. Mugịt, fallecido en 532/1137. Cf. Penelas y Zanón, "Nómina de ulemas", n. ${ }^{\circ} 2503$.

${ }^{76}$ Muhammad b. Naŷŷāh al-Dahabī al-Umawī (455-532/1063-1137). Cf. Ibn Baškuwāl, Kitāb al-Șila, n. ${ }^{\circ}$ 1166; al-Dabbī, Bugyat al-multamis, n. ${ }^{\circ}$ 290; Ibn Haŷar al-'Asqalānī, Lisān al-mīzān, Beirut, 1971, 7 v., V, 404, n. 1325.

77 No creo que sea el régulo de Murcia. Por la fecha, podría tratarse de Muhammad b. Ahmad b. Muhammad b. Tāhir (m. 552/1157), residente en Sevilla, o un homónimo suyo de Guadix, fallecido después de 545/1150. Para el primero, cf. Ibn Baškuwāl, Kitāb

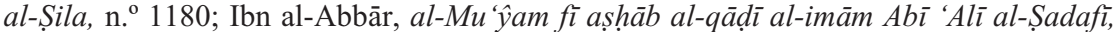
F. Codera (ed.), Madrid, 1885, n. ${ }^{\circ}$ 133; para el segundo, Takmila, ed. al-Ḥusaynī, n. ${ }^{\circ} 1305$; ed. Codera, n. ${ }^{\circ} 662 ;$ Dayl, VI, 88.

Al-Qanțara (AQ) XXX 2, julio-diciembre 2009, pp. 361-401 ISSN 0211-3589 
Masarra ${ }^{78}$, Abū Bakr Yahyyà b. Sa āda ${ }^{79}$ y otros. Además aprendió el $a d a b$ con Abū Bakr Ibn Fandila ${ }^{80}$, Abū 1-Walīd Ibn Haŷŷāŷ ${ }^{81}$, Abū 1-Ṭāhir al-Tamīmī ${ }^{82}$, Abū 'Abd Allāh Ibn Abī 1-Jiṣāl ${ }^{83}$, Abū 1-Qāsim Ibn al-Rammāk ${ }^{84}$ y otros. Le dieron licencia (îy $\left.\bar{a} z a\right)$ para transmitir Abū 1-Hasan Ibn Nāfi', Abū 1-Haŷŷâŷ al-Qựāa'ì, Abū 1-Ḥasan Ibn Mawhab ${ }^{85}$ y Abū 'Abd Allāh Ibn Waḍḍạ̄ ${ }^{86}$.

Almocrí en la mezquita aljama de Córdoba y en la mezquita de Umm Mu'āwiya, con él estudiaron su hijo Gālib, su nieto 'Ayyāš b. Muhammad (n. ${ }^{\circ}$ 12) y el hijo de su hermano Muhammad b. Aḥmad (n. $\left.{ }^{\circ} 11\right)$. Además de Corán, enseñaba hadiz, lengua árabe y adab. Su importancia dentro del mundo del saber se puede medir por el número de sus discípulos. Según Zanón es uno de los maestros más citados en la Takmila de Ibn al-Abbār, concretamente aparece veinte veces como maestro ${ }^{87}$. Es precisamente este autor quien nos describe sus cualidades científicas: «conocedor de las lecturas coránicas y sus métodos, señero por la calidad y perfección de su recitación, experto en lengua árabe, también tenía aptitudes para la declamación poética». Su dedi-

78 'Abd al-Malik b. Masarra b. Faraŷ b. 'Azīz (m. 552/1157). Cf. Penelas y Zanón, "Nómina de ulemas", n. ${ }^{\circ} 1066$.

${ }^{79}$ M. 543/1148. Ibidem, n. ${ }^{\circ} 2412$.

${ }^{80}$ Puede tratarse de Muhammad b. 'Abd al-Gānī b. 'Umar b. 'Abd Allāh b. Fandila (444-535/1052-1139). Cf. İ̉n Baškuwāl, Kitāb al-Ṣila, n. ${ }^{\circ}$ 1168, y al-Ḍabbī, Bugyat al-multamis, . $^{\circ} 210$.

${ }^{81}$ Debe de ser Ismā'îl b. 'İsà b. 'Abd al-Rahmān b. Haŷŷāŷ (447-534/1055-1139). Cf. su biografía en Takmila, ed. al-Husaynī, n. ${ }^{\circ}$ 488; ed. Bel y Ben Cheneb, n. ${ }^{\circ} 488$.

${ }^{82}$ Muhammad b. Yūsuf b. 'Ảbd Allāh b. Yūsuf b. 'Abd Allāh b. Ibrāhīm al-Aštarkūnī (m. 438/1046). Cf. Ibn Baškuwāl, Kitāb al-Șila, n. ${ }^{\circ}$ 1175; al-Dabbī, Bugyat al-multamis, n. ${ }^{\circ}$ 1552; Ibn al-Abbār, al-Mu 'ŷam, n. ${ }^{\circ}$ 124; Ihạța, II, 521; al-Suyūṭ̂̄, Bugyat al-wu'ā, I, 279, n. ${ }^{\circ}$ 514; Kaḥhāla, Mu 'ŷam, XII, 129; Monroe, J.T., "Al-Saraqusțī, ibn al-Ashtarkuwī: Andalusi Lexicographer, Poet and Author of al-Maqāmāt al-Luzūmīya", Journal of Arabic Literature, XXVIII, 1 (1997), 1-37; Ferrando Frutos, I., "La Maqāma barbariyya de al-Saraqustī”, Anaquel de Estudios Árabes, 2, 1991, 119-129.

83 465-540. Cf. Penelas y Zanón, "Nómina de ulemas", n. ${ }^{\circ} 2215$.

${ }^{84}$ M. 541. Cf. Ibidem, n. ${ }^{\text {O }} 787$.

85 'Alī b. 'Abd Allāh b. Muhammad b. Sa'īd b. Mawhab, Ibn al-Zaqqāq (441-532/1049-1137). Cf. Ibn Baškuwāl, Kitāb al-Sila, n. ${ }^{\circ}$ 913; al-Dabbī, Bugyat al-multamis, n. ${ }^{\circ}$ 1222; al-Suyūțī, Kitāb Țabaqāt al-mufassirīn, Beirut, 1980, 68, n. ${ }^{\circ}$ 73; Ibn al-Ŷazarī, Gāyat al-nihāya, I, 554, n. ${ }^{\circ}$ 2262; Kaḥhāla, Mu'ŷam, VII, 140.

${ }^{86}$ Debe de ser Muhammad b. Mūsà b. Waḍ̣ạh al-Qaysī (m. 539), cuya biografía recoge Ibn Baškuwāl, Kitāb al-Sila, n. ${ }^{\circ} 1176$.

87 Zanón Bayón, "La vida intelectual en al-Andalus", 37. Debe tenerse en cuenta que la relación de maestros citados con más frecuencia en esta obra incluye un total de 84 ulemas, estando al-Šarrāt en la parte baja de la tabla, y que algunos aparecen citados hasta 192 veces, como Ibn al-'Arabī, o 139, caso de su maestro Šurayḥ b. Muhammad.

Al-Qanțara (AQ) XXX 2, julio-diciembre 2009, pp. 361-401 ISSN 0211-3589 
cación a la poesía se refleja en la biografía de su hija en el Dayl, donde se recogen unos versos atribuidos a él y se dice que compuso poemas de tema ascético. Precisamente Ibn al-Abbār nos habla de su ascetismo, piedad y virtud.

Ibn Gālib había nacido en el año 511/1117 ó 512, según testimonio propio, pero su nieto Abū l-Qāsim Ibn al-Taylasān afirmaba que su nacimiento tuvo lugar sin duda en el año 511/1117. Murió en Córdoba antes del mediodía del domingo 2 de ŷumādà II —Ibn 'Abd al-Maŷīd dice que al final de ŷumādà II- del año 586/8 julio 1190, después de haber vivido largo tiempo, y fue enterrado el lunes siguiente por la tarde en el cementerio de Umm Salama, a la salida de la Bāb al-Hudà, delante de la tumba de 'Abd al-Malik b. Habīb. Le rezó su hijo Gālib y se dice que no faltó a su entierro ningún grande de la jāșșa ni la 'āmma.

9) Fāṭima bint Abī l-Qāsim 'Abd al-Raḥmān b. Muḥammad b. Gālib al-Qurțubī al-Šarrāt, Umm al-Fath ${ }^{88}$.

Casada con Muhammad b. Aḥmad Ibn al-Ṭaylasān, fue madre de Aḥmad y de al-Qāsim.

Estudió con su padre la recitación coránica (talat al-Qur'ān) en la lectura de Nāfi‘ y otras obras de hadiz, fiqh y lengua, como al-Tanbīh de Makkī, al-Šihāb de al-Quḍā'ì y al-Mujtașar de al-Țulaytulī; con él confrontó al-Ṣahịh de Muslim, al-Tahdīb de Ibn Hišām, al-Kāmil de al-Mubarrad, al-Amālī y al-Nawādir de al-Qālī. También le oyó sus poesías sobre ascetismo, que aprendió de memoria.

Además leyó el Corán (qara'at al-Qur'ān) con Abū 'Abd Allāh al-Andarāšī (Andūŷārī) al-Zāhid, también llamado por Ibn al-Zubayr al-Mudawwarī, de los abdāl ${ }^{89}$, y con Abū 'Abd Allāh Ibn al-Mufaddal al-Kafíf ${ }^{90}$. Cree su hijo Abū l-Qāsim que ella también tenía iŷāza de Abū Marwān Ibn Masarra ${ }^{91}$. Fue este sabio el que le puso el nombre y la bendijo cuando se la llevó su padre de recién nacida.

${ }^{88}$ Takmila, ed. Codera, 748, n. ${ }^{\circ}$ 2124; Dayl, VIII (2), 490, n. ${ }^{\circ}$ 269; Ibn al-Zubayr, Silat al-Sila, V, 314-15, n. ${ }^{\circ}$ 631; Dahabī, Ta'rīj al-Islām, XLIV (años 610-620), 162, n. ${ }^{\circ} 169$; Ávila, "Las mujeres sabias", 156, n. ${ }^{\circ} 25$.

${ }^{89}$ No lo he encontrado entre los ascetas de su época y no creo que se trate de $\mathrm{Mu}$ hammad b. Aḥmad b. Muḥammad al-Anșārī al-Andarašī, conocido por Ibn al-Balansī e Ibn al-Yatìm (544-621/1150-1214, Dayl, VI, 44, n. $\left.{ }^{\circ} 90\right)$, porque no era asceta y porque recibió îyāza de Abū l-Qāsim al-Šarrāt sin conocerlo.

${ }^{90}$ No he podido encontrar con este nombre más que a Ahmad b. al-Mufaḍdal b. Muhammad b. Balŷūn al- 'Âmirī, transmisor de Abū 'Alī al-Ṣadafī, del que se ignora si era ciego. Cf. Dayl, I-2, 550, n. ${ }^{\circ} 839$.

${ }_{91}$ Cf. Penelas y Zanón, "Nómina de ulemas", n. ${ }^{\circ} 1066$.

Al-Qanțara (AQ) XXX 2, julio-diciembre 2009, pp. 361-401 ISSN 0211-3589 
Su hijo Abū 1-Qāsim Ibn al-Ṭaylasān (n. ${ }^{0}$ 5) recitó con ella el Corán según la lectura de Warš y estudió con ella los libros que ella había estudiado con su padre, recibiendo $i \hat{y} \bar{a} z a$ de su puño y letra.

Falleció en el año 613/1216-17.

10) Gālib b. 'Abd al-Raḥmān b. Muḥammad b. Gālib (Jalaf) al-Anșārī, Abū Bakr y Abū Tammān, al-Šarrāt ${ }^{92}$.

Natural de Córdoba, era hijo de Abū l-Qāsim al-Šarrāṭ.

Aprendió la recitación (talā) de las siete lecturas coránicas de su padre y de Abū Bakr Ibn Jayr, pues estudió con los dos (sami 'a) y también con Abū l-Qāsim Ibn Baškuwāl. Otros maestros fueron Abū Ishāà Ibn Ṭalḥa ${ }^{93}$, Abū Bakr al-Zar'ālī (al-Zargālī), Abū l-Ḥasan 'Abd al-Raḥmān b. Abī 1-Qāsim b. Baqī "94, Abū 1-Hasan Ibn 'Aqqāb ${ }^{95}$, Abū 'Abd Allāh Ibn Hafṣ, Abū 'Abd Allāh Ibn 'Irāq ${ }^{96}$, Abū 'Abd Allāh Ibn 'Alī al-Lāridī ${ }^{97}$, Abū 1-'Abbās Ibn Maḍā' y Abū Muhammad Ibn Yazīd al-Sa'dī ${ }^{98}$. Le concedió $i \hat{y} \bar{a} z a$ un grupo de los más grandes, entre ellos Abū 1-Hasan Ibn Hunayn, Abū 1-Hasan Ibn Kawtarar ${ }^{99}$, Abū Muhammad 'Abd al-Ḥaqq Ibn Bunuh ${ }^{100}$ y Abū Muhammad al-Qāsim b. Dahmān ${ }^{101}$.

Hombre de ciencia y práctica religiosa (min ahl al- ilm wa-l-'amal), se menciona que, además de ilustre almocrí y tradicionista, era un ex-

92 Biografía en Takmila, ed. Codera, 699, n. ${ }^{\circ}$ 1959; Dayl, V (2), 519, n. ${ }^{\circ}$ 985; Ibn al-Zubayr, Silat al-Sila, IV, 178, n. $^{\circ}$ 354. En Takmila aparece Jalaf por Gälib, lo que sin duda es un error de lectura. Respecto a la kunya, en Takmila sólo aparece Abū Bakr, mientras que Dayl da las dos.

$93 \mathrm{~V}$. nota 54.

94 Parece ser hijo del mencionado en nota 40, con lo cual habría que añadir un miembro más a esta familia, cuyo árbol genealógico trazó M. Marín en "Baqī b. Majlad y la introducción del estudio del hadīt en al-Andalus", Al-Qanțara, I (1980), 165-208, a pesar de que no ha sido posible encontrar su biografía.

95 Se trata de "Alī b. Muhammad b. Ahmad al-Anșārī (m. 574). Cf. Penelas y Zanón, "Nómina de ulemas", n. ${ }^{\circ} 12 \dot{9} 2$.

96 V. nota 64.

97 Quizá sea Muhammad b. 'Atīq b. 'Alī b. 'Abd Allāh, aunque pertenece a su misma generación, pues nació en 563/1167 y falleció con posterioridad a él. Cf. ibidem, n. 2052.

98 Podría identificarse con 'Abd Allāh b. al-Hasan b. 'Abd Allāh b. Yazīd al-Sa'dī, si no fuera porque falleció en 557/1161 ó 559/1163 al tiempo del nacimiento de su supuesto discípulo. Cf. ibid., n. ${ }^{\circ} 903$.

${ }_{99}$ Se trata de 'Alī b. Ahmad b. Muhammad b. Kawtar (529-589/1134-1193). Cf. ibid., n. ${ }^{\circ} 1187$.

100 'Abd al-Haqq b. 'Abd al-Malik b. Būnuh b. Sa'īd (504-586/1114-1190). Cf. Penelas y Zanón, “Nómina de ulemas”, n. ${ }^{\circ} 712$.

101 Debe de ser al-Qāsim b. Muhammad b. 'Abd al-Rahmān b. al-Qāsim b. 'Abd al-Raḥmān b. Daḥmān, fallecido alrededor del año 620/1223. Cf. ibidem, n. ${ }^{\circ} 1522$.

Al-Qanțara (AQ) XXX 2, julio-diciembre 2009, pp. 361-401 ISSN 0211-3589 
celente gramático. Su pericia en lecturas coránicas se vio adornada por la hermosa voz que se decía que poseía recitando el Corán y el hadiz. Enseñó estas materias y también lengua árabe y letras.

Parece el heredero de toda la transmisión de su padre y, de hecho, todavía en vida de éste enseñó (aqra'a) mucho en el maŷlis de al-Šarrāt, se supone que en la mezquita de Umm Mu'āwiya, donde continuó ejerciendo cuando su padre murió. Entre los que transmitieron de él se encuentran el hijo de su hermana Abū 1-Qāsim Ibn al-Ṭaylasān y Abū 1-Walīd Ibn al-Ḥāŷy ${ }^{102}$.

Se dice que fue muy querido por la nobleza (jāssa) y el pueblo, seguramente debido a las cualidades que lo adornaban, pues no sólo era brillante en la conversación y buen contertulio, sino que se distinguió por su virtud, ascetismo y generosidad.

Nació entre las dos oraciones de la víspera del miércoles 18 de ŷumādà II del 559/13 mayo 1164 y murió en el primer cuarto de la noche del sábado 6 de rabī‘ II del 600/13 diciembre 1203. Fue enterrado junto a su padre en el cementerio de Umm Salama. Le rezó su cuñado (sihr), el imán de la oración preceptiva en la mezquita mayor Abū 'Abd Allāh Ibn 'Ayyāš al-Muqri' al-Šintiyālī (n. $\left.{ }^{\circ} 13\right)$.

11) Muḥammad b. Aḥmad b. Muḥammad b. Gālib al-Anșārī, conocido por Ibn al-Šarrāt, Abū 'Abd Allāh, y al-Ustād Ḥamad ${ }^{103}$.

De Córdoba.

Como otros miembros de su familia, era almocrí y también piadoso y asceta.

Estudió con su tío paterno Abū l-Qāsim 'Abd al-Raḥmān b. Muhammad b. Gālib (n. ${ }^{\circ} 8$ ) las siete lecturas coránicas y transmitió de él y de Abū Darr al-Jušanī ${ }^{104}$ y Abū 'Abd Allāh Muhammad b. 'Uțmān b. Baqīmīs ${ }^{105}$.

Enseñó en la mezquita mayor de Córdoba Corán, lengua árabe, lexicografía y hadiz. Transmitieron de él Abū 'Umar Yahyà b. Ubayy,

102 V. las fuentes para su biografía en ibid., n. ${ }^{\circ} 1741$.

103 Biografía en Takmila, ed. al-Husaynī, 602, n. ${ }^{\circ}$ 1589; ed. Codera, 317, n. ${ }^{\circ}$ 945; Dayl, VI, 55, n. ${ }^{\circ}$ 108; al-Suyūtī, Bugyat al-wu'ā, I, 45, n. ${ }^{\circ} 73$; Ibn al-Ŷazarī, Gāyat al-nihāya, II, 86, n. ${ }^{\circ}$ 2798; al-Dahabī, Tabaqāt al-qurrā', III, 1110, n. ${ }^{\circ}$ 1019; Vizcaíno Plaza, "Lectores del Corán", n. 303.

${ }^{104}$ Mus'ab b. Abī Bakr Muhammad b. Mas'ūd b. 'Abd Allāh b. Mas'ūd, Ibn Abī 1-Rakab (533-603/1138-1206). Penelas y Zanón, “Nómina de ulemas”, n. ${ }^{\circ} 2298$.

105 Ibidem, n. ${ }^{\circ} 2053$.

Al-Qanțara (AQ) XXX 2, julio-diciembre 2009, pp. 361-401 ISSN 0211-3589 
su pariente (qarīb) Abū 1-Qāsim al-Qāsim Ibn al-Ṭaylasān (n. ${ }^{0}$ 5), Abū 1-Qāsim al-Qāsim Ibn al-Așfar ${ }^{106}$ e Ibn Rabī' 107.

Murió el jueves y fue enterrado el viernes 11 de muharram del año 616/29 marzo 1219 en el cementerio de Umm Salama, aunque Abū Ŷa'far Aḥmad b. 'Alī al-Qurțubī, compañero (șạhib) de Ibn al-Abbār, le dijo a éste que ocurrió a mediados de muharram/2 abril. La primera fecha la registra Ibn al-Ṭaylasān.

\section{Banū 'Ayyāšs al-Jazrầ̃}

12) 'Ayyāš b. Muḥammad b. Aḥmad b. Jalaf b. 'Ayyāšs al-Qurțuīi al-Anșārī al-Jazrầī, conocido por al-Šintiyālī, Abū Bakr ${ }^{108}$.

Almocrí, ustād, jațīb y tradicionista, se dice que era piadoso, virtuoso y asceta (nasak). Regentó la jațāba y fue imán en la aljama de Córdoba durante un tiempo.

Tomó las lecturas coránicas de su padre, de su abuelo materno Abū 1-Qāsim Ibn Gālib al-Šarrāt (n. ${ }^{\circ}$ 8) y de su tío materno Abū Bakr Gālib (n. ${ }^{\circ}$ 10). Escuchó las lecciones de Abū 1-Qāsim Ibn Baqī ${ }^{109}$ y transmitió del almocrí y jațīb Abū Ya'far Aḥmad b. Yahyà al-Himyarī ${ }^{110}$, del cadí Abū 1-'Abbās Yahyà b. 'Abd al-Raḥmān Ibn al-Ḥâŷy al-Maŷrīịīi ${ }^{111}$ y otros. Le dieron îyāza Abū Bakr Ibn Jayr ${ }^{112}$, Abū 1-Ḥakam Ibn Hậŷâŷy ${ }^{113}$ y Abū 1-'Abbās Ibn Miqdām ${ }^{114}$.

106 Al-Qāsim b. Muhammad b. 'Alī al-Anșārī al-Ḥārițī (591-676). Ibid., n. ' 1523.

107 Tal vez se trate del cadí Yahyà b. 'Abd al-Raḥmān Ibn Rabī', primero de la relación de cadíes nazaríes establecida por Calero Secall ("Cadíes supremos", 150, nota 7, y "Dinastías de cadíes", 4).

108 Takmila, ed. Codera, 695, n. ${ }^{\circ}$ 1951; Dayl, V (2), 487, n. ${ }^{\circ}$ 884; Ibn al-Zubayr, Silat al-Sila, ed. E. Lévi-Provençal, 157, n. ${ }^{\circ}$ 311; ed. 'A.S. al-Harrās, IV, 168, n.' 337; Ibn al-Ŷ́azarī, Gāyat al-nihāya, I, 607, n. o 2483; al-Dahabī, Tabaqāt al-qurrā', II, 1098, n. ${ }^{\circ}$ 998; Vizcaíno Plaza, "Lectores del Corán”, n. ${ }^{\circ} 206$.

109 V. nota 40.

110 Ibn Sa‘īd, al-Mugrib fi ḥulà l-Magrib, Š. Dayf (ed.), El Cairo, 1953-55, I, 220, n. ${ }^{\circ} 149$.

111 V. nota 39

112 Sobre este autor, v. Vizcaíno Plaza, J.M., La Fahrasa de Ibn Jayr (m. 575/1180), $E O B A$, XII, Madrid, 2002.

113 Se trata de Abū l-Haŷŷâŷ b. Muhammad b. 'Amr b. Aḥmad (522-601). Cf. Penelas y Zanón, "Nómina de ulemas", n. 796.

114 Se trata del sevillano Abū 1-'Abbās Aḥmad b. Muhammad b. Aḥmad b. Miqdām al-Ru'aynī, también llamado Abū 1-Qāsim (512-604). V. Takmila, ed. Codera, 97, 
Transmitieron de él su hijo Abū 'Abd Allāh y Abū 'Abd Allāh Ibn al-Mu'adِdin al-Mubārak al-Muqri' ${ }^{115}$.

Respecto a la fecha de su muerte, no se ponen de acuerdo los distintos autores. Ibn al-Abbār dice que murió en Málaga en el año 640/1242-43 y fue enterrado el mismo día que el cadí Abū 'Āmir Yahyà b. 'Abd al-Raḥmān Ibn Rabī' 116. Recoge también el testimonio de Abū Hayyān, según el cual el fallecimiento de Ibn Rabī' tuvo lugar el 10 de rabī' I del 639/18 septiembre 1241, en lo que coincide Ibn al-Ŷazarī. Ibn al-Zubayr, por su parte, da el mismo año, pero cambia el día a 9 de rabī' II de 639/17 octubre 1241. Ibn Rabī' podría servir para fijar la fecha, si no fuera porque también para su muerte se dan tres años, 637, 639 y 640. Respecto al nacimiento de 'Ayyāš, tenemos dos fechas: 561/1165-66 y mediados de raŷab del 572/11 enero 1177 .

13) Muhammad b. Aḥmad b. Jalaf b. 'Ayyāš al-Anșārī al-Jazrâ̂ī, Abū 'Abd Allāh al-Šintiyālī ${ }^{117}$.

Dirigió la oración preceptiva (șạhib al-şalā) en la mezquita mayor de Córdoba alrededor de treinta años. Allí enseñó Corán y hadiz durante largo tiempo, y aprendió de él un grupo, entre ellos, Abū l-Qāsim Ibn al-Ṭaylasān.

Gran amigo (șạhịb) de Abū 1-Qāsim Ibn Baškuwāl, escuchó las lecciones de éste, que le concedió iŷāza para todo lo que transmitió y compuso, y le legó los libros de su biblioteca.

Tomó las siete lecturas coránicas (talā $b i-l-s a b)$ de su suegro (șihr) Abū 1-Qāsim Ibn Gālib al-Šarrāt y la mayor parte de sus libros de hadiz, lengua árabe y lexicografía. También tomó las lecturas coránicas de Abū Ishāa Ibn Talḥa ${ }^{118}$, Abū 'Abd Allāh Ibn Sālim b. Bartāl ${ }^{119}$ y Abū l-'Abbās Ibn Șālih al-Ḍarīr 120; la lectura de Nāfi' de

n. ${ }^{\circ}$ 252; ed. Bel y Ben Cheneb, 119, n..$^{\circ} 252$; Dayl, I (1), 384, n. ${ }^{\circ}$ 537; al-Dahabī, Ma 'rifat al-qurrā' al-kibār 'alà l-țabaqāt wa-l-a 'ṣār, Beirut, Mu'assasat al-Risāla, 1408/[1988], II, 585, n. ${ }^{\circ}$ 544; Ibn al-Ŷazarī, Gãyat al-nihāya, I, 104, n.o 478; Ibn al-Qāḍī, Ŷadwat al-iqtibās fì dikr man halla min al-a 'ām madīnat Fās, Rabat, 1973-74, I, 144, n. ${ }^{\circ} 94$.

115 Debe de tratarse de Muhammad b. al-Hasan b. "Alī b. Muhammad b. Šaddād b.

Ṭufayl al-Murādī. Cf. Penelas y Zanón, "Nómina de ulemas”, n. ${ }^{\circ} 1804$.

116 V. nota 107.

117 Biografía en Takmila, ed. al-Husaynī, 586, n. ${ }^{\circ} 1560$; ed. Codera, 301, n. ${ }^{\circ}$ 916; Dayl, V (2), 626, n. ${ }^{\circ}$ 1192; Ibn al-Ŷazarī, Gāyat al-nihāya, II, 62, n. ${ }^{\circ} 2723$; Vizcaíno Plaza, "Lectores del Corán", n. ${ }^{\circ} 298$.

118 V. nota 54.

119 Penelas y Zanón, "Nómina de ulemas", n. ${ }^{\circ} 1850$.

120 V. nota 66.

Al-Qanțara (AQ) XXX 2, julio-diciembre 2009, pp. 361-401 ISSN 0211-3589 
Abū Bakr Ibn Samaŷūn ${ }^{121}$; oyó de Abū 1-Hasan 'Alī b. Muhammad b. 'Aqqāb ${ }^{122} a l-S ̌ i h a \bar{b} b$ de al-Quḍā'ī; de Abū l-Hasan 'Abd al-Raḥmān b. Ahmmad b. Baqī ${ }^{123}$ la Risāla de Ibn Abī Zayd; de Abū Bakr Ibn Jayr, de Abū 1-Qāsim al-Suhaylī ${ }^{124}$ y de Abū Muhammad Ibn al-Ṣaffār ${ }^{125}$, entre otros. Le dio iŷāza Abū 1-Ḥasan Ibn Hunayn.

Transmitieron de él su hijo Abū Bakr 'Ayyāš y Abū 'Alī al-Ḥusayn Ibn al-Mālaqī y sus hijos Abū Hāmid Muhammad, Abū 1-Ḥasan y Abū Muhammad; y Abū 'Imrān, hijo de su hermano Abū 1-Qāsim 'Abd al-Raḥmān; Abū 'Umar Ibn Hawt Allāh y Abū 1-Qāsim Ibn al-Ṭaylasān (n. ${ }^{\circ}$ 5).

El párrafo anterior aparece literalmente así en Dayl. No queda claro si Abū 'Imrān era hijo de su hermano o del hermano de Ibn al-Mālaqī. De éstos y de los tres hijos de Ibn al-Mālaqī sólo he podido documentar a un tal Abū Muhammad 'Abd Allāh b. Muhammad b. 'Īsà al-Ansāāī Ibn al-Mālaqī ${ }^{126}$. Existen varios Abū 'Imrằn Mūsà b. 'Abd al-Raḥmān que no creo que estén relacionados con ninguno de los dos. Queda, pues, abierta la posibilidad de que este Muhammad tuviera otro hermano 'Abd al-Raḥmān y un sobrino Abū 'Imrān.

Ilustre almocrí, destacado en ortología, y tradicionista, fue hăfiz en fiqh y cultivó además otras ciencias como gramática, partición de herencias (farā'iḍ) y his āb. En su biografía se alaban sus cualidades, diciendo que era virtuoso, famoso por su piedad y humildad, sabio, trabajador y esforzado en la piedad ( 'ibāda).

Murió la mañana del lunes 12 de ša 'bān del año 609/7 enero 1213 y fue enterrado la tarde del martes siguiente en el cementerio de Umm Salama en la misma rawộa que su suegro Abū 1-Qāsim Ibn Gālib y que el hijo de éste Abū Bakr Gālib. Su entierro fue muy concurrido por gente de su generación, sin que faltara ningún grande ${ }^{127}$.

Nació entre los años 534 y 535/1139-40.

121 V. nota 47.

122 V. nota 95.

123 V. nota 90.

124 Ibidem, n. ${ }^{\circ} 750$.

125 Ibid., n. ${ }^{\circ} 1012$.

126 Takmila, ed. al-Husaynī, 852, n. ${ }^{\circ}$ 2058; ed. Codera, 486, n. ${ }^{\circ}$ 1394; Ibn 'Askar, A 'lām Mālaqa, 221, n. ${ }^{\circ}$ 64; Ibn Ibrāhīm, al-I'lām bi-man halla Marrākuš wa-Agmāt min al-a 'lām, Rabat, 1974-1983, VIII, 193, n. ${ }^{\circ} 1150$.

127 Esta rawda es una de las cuatro documentadas en época almohade. V. Zanón Bayón, J., Topografía de Córdoba almohade a través de las fuentes árabes, Madrid, 1989, 84.

Al-Qanțara (AQ) XXX 2, julio-diciembre 2009, pp. 361-401 ISSN 0211-3589 
14) Muhammad b. 'Ayyāš b. Muḥammad b. Aḥmad b. Jalaf b. 'Ayyāš al-Jazraŷī al-Qurțubī, Abū 'Abd Allāh ${ }^{128}$.

Hijo de Abū Bakr.

Estudió (qara'a) con Qāsim b. Muhammad Ibn al-Ṭaylasān al-Awsī (n. ${ }^{\circ}$ 5) y con él lo hicieron 'Abd Allāh b. 'Alī b. Salmūn ${ }^{129}$ y

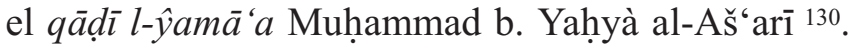

Creo que se trata del mencionado en la biografía de Abū l-Qāsim Ibn al-Ṭaylasān como yerno suyo y maestro de Ibn 'Abd al-Malik al-Marrākušī, pues difícilmente la que fuera su mujer, que tuvo que nacer antes del fallecimiento de su padre en el 642, pudo casarse con el siguiente biografiado que nació en el 688. Lo confirma la información de al-Maqqarī, recogida en el n. ${ }^{\circ} 16$.

15) Muhammad b. Muhammad b. 'Ayyāš b. Muhammad b. Aḥmad b. Jalaf b. 'Ayyāš al-Jazraŷī al-Qurțubī, Abū 'Abd Allāh ${ }^{131}$.

Cadí supremo de Granada.

Menciona Ibn al-Jațīb entre los cadíes de Yūsuf I a Abū 'Abd Allāh Muhammad b. 'Ayyāšs, pero sin duda eliminó un eslabón de la cadena genealógica y se trata de Muḥammad b. Muḥammad b. 'Ayyāš, y no de su padre (n. $\left.{ }^{\circ} 14\right)$, ya que su abuelo falleció en 639/1241 y difícilmente su padre estaría vivo en 740/1339, época en la que éste ejerció el cadiazgo. En al-Durar al-kāmina aparece su nombre como Muhammad b. Muhammad b. Muhammad b. 'Ayyāš. No obstante, su biografía en esa obra corresponde a Muhammad b. Muhammad, tanto por el hecho de haber sido cadí supremo de Granada, como por los maestros que se mencionan, de una generación anterior a la suya.

De él se recuerda su origen cordobés, señalándose que su antepasado 'Ayyāš, el más próximo, fue el último jațīb de la aljama de Córdoba. Él nació en Málaga en ramaḍān del año 688/septiembre 1289.

128 Biografía en Ibn al-Ŷazarī, Gāyat al-nihāya, II, 223, n. ${ }^{\circ} 3338$; Vizcaíno Plaza, "Lectores del Corán", n. ${ }^{\circ} 331$.

129 669-741/1270-1340. Cf. Ihāạta, III, 400; Ibn al-Qāḍī, Ŷadwat al-iqtibās, II, 434, n. ${ }^{\circ} 464$.

130 Calero Secall, "Cadíes supremos", 139-40 y nota 23.

131 Biografía en al-Bunnāhī, al-Marqaba al- 'ulyā, 20-21 y 148; A. Cuellas Marqués (ed.), 35-36 texto árabe y trad. 139; Ihạtạ, IV, 320; Ibn al-Jațīb, al-Lamha al-badriyya fi l-dawla al-nașriyya, Beirut, 1980, 104; Historia de los reyes de la Alhambra: el resplandor de la luna llena: (Al-Lamha al-badriyya), estudio preliminar E. Molina López, trad. e introd. J.M. ${ }^{a}$ Casciaro Ramírez, Granada, 1998, 114; Ibn al-Qādīi, Durrat al hiŷăl, II, 267, n. ${ }^{\circ} 769$; Ibn Ḥaŷar, al-Durar al-kāmina, IV, 345, n. ${ }^{\circ} 4462$; Calero Secall, "Cadíes supremos", 139 y nota 24, e idem, Cadies del reino nazari, 14-16.

Al-Qanțara (AQ) XXX 2, julio-diciembre 2009, pp. 361-401 ISSN 0211-3589 
Entre sus maestros se cita a su padre Abū 'Abd Allāh Muhammad Ibn 'Ayyāšš ${ }^{132}$, de quien aprendió el Corán y parte del Kitāb al-Musalsalāt de Abū l-Qāsim Ibn al-Ṭaylasān, que lo había oído a su autor. Estudió (qara'a) también con Abū Bakr Muhammad b. 'Alī Ibn al-Fajjār ${ }^{133}$, Sa'īd b. Ibrāhīm b. 'Īsà, Abū Zayd 'Abd al-Raḥmān b. Aḥmad al-Lawšī 134, Abū 'Abd Allāh Ibn Bakr ${ }^{135}$, y Abū Muḥammad Ibn Abī l-Saddād (m. 705/1305) ${ }^{136}$.

Alfaquí, muftí y también asceta, este Muhammad se dedicó al fiqh especialmente, escribiendo él mismo sus obras; poseía una bella caligrafía. Se dice que fue el cadí más sabio de su tiempo en sentencias (ahkām), el que mejor conocía las cuestiones jurídicas (masā'il) y el más experto en casos específicos (nawāzil).

Después del fallecimiento del cadí Abū 'Abd Allāh Muhammad b. Yahyà b. Bakr, en la batalla del Salado o de Tarifa (741/1340), Yūsuf I lo llamó a su presencia, nombrándolo cadí supremo y encargado de la jutba de los viernes en la mezquita de la Alhambra. Sin embargo, no regentó el cadiazgo más que durante tres días, ejerciendo desinteresadamente, sin aceptar vestidos ni retribución, puesto que ya había pensado dejarlo. Al cuarto día solicitó la dispensa del cargo y también dejó la juṭba, habiendo predicado un único viernes ${ }^{137}$. Lo sucedió en el cadiazgo el alfaquí Abū Bakr Aḥmad b. Muḥammad b. Barțāl, también malagueño ${ }^{138}$.

132 En al-Durar al-kāmina lo llama abuelo por error, ya que, como se ha visto, añade un elemento más al nasab.

${ }_{133}$ M. 723/1323. Ihātata, III, 91; al-Dībāŷy al-mudhab, II, 288; Ibn Haŷar, al-Durar al-kāmina, IV, 199, n. ${ }^{\circ}$ 4088; al-Suyūṭī, Bugyat al-wu' 'ā, I, 187-188 (312); Ibn Ibrāhīm, al-I'lām, IV, 351, n. ${ }^{\circ}$ 59; Majlūf, Saŷara, I, 212, n. ${ }^{\circ}$ 744; Kaḥhāla, Mu '̂yam, XI, 42.

134 Según Calero Secall (Cadies del reino nazarí, 18, nota 18) es un jațỉb de Málaga, cuya biografía se encuentra en al-Dībâŷ al-mudhab, I, 393-394.

135 Identificado por Calero Secall (Cadies del reino nazarí, 18, nota 19) como Muhammad b. Yahyà b. Bakr al-Aš‘ arī, su antecesor en el cargo.

136 Se trata de 'Abd al-Wāhid b. Muhammad b. 'Alī Ibn Abī l-Saddād. Cf. Ihạtta, III, 553; al-Dībāŷy al-mud̆hab, II, 63; al-Suyūțī, Bugya al-wu'ā, II, 121-122, n. ${ }^{\circ}$ 1595; Ibn al-Ŷazarī, Gāyat al-nihāya, I, 477, n. ${ }^{\circ}$ 1985; Kạ̣hāạ, Mu'ýam, VI, 212 y 212-213.

137 Aparece mencionado de pasada en la parte dedicada al rechazo de los cargos en el artículo de Damaj, A.C., "Punto de vista del intelectual sobre su relación con el poder político en la época nazar'", Anaquel de Estudios Árabes, 15 (2004), 107.

138 Sobre este cadí, v. Velázquez Basanta, F.N., "Ibn Bartāl (s. XIV): un malagueño "iletrado" en el cadiazgo supremo de Granada", en Estudios árabes dedicados a D. Luis Seco de Lucena (en el XXV aniversario de su muerte), C. Castillo Castillo, I. Cortés Peña y J.P. Monferrer Sala (eds.), Granada, 1999, 271-276.

Al-Qanțara (AQ) XXX 2, julio-diciembre 2009, pp. 361-401 ISSN 0211-3589 
Tras abandonar el cadiazgo de Granada, volvió a su ciudad natal, Málaga. Allí fue encargado de la oración (salā) y jațīb de la mezquita mayor, cargos en los que se mantuvo hasta su muerte, sin percibir retribución alguna en toda su vida.

Murió en 759/1357-58.

16) Muhammad b. Muḥammad b. Muhammad b. 'Ayyāš b. Muhammad b. Ahmad b. Jalaf b. 'Ayyāš al-Anșārī al-Jazraŷī al-Qurțubī de origen, después al-Mālaqī, Abū 'Abd Allāh ${ }^{139}$.

Bajo este epígrafe aparece en al-Durar al-kāmina la biografía del anterior, seguramente por una confusión de Ibn Hayaar, debida a la existencia de un Muhammad b. Muhammad b. Muhammad b. 'Ayyāš. Éste es mencionado por al-Maqqarī (m. 1041/1632), quien dice que su abuelo (o antepasado) estudió con él (qara') la Zaharāt al-Basātīn de Abū 1-Qāsim Ibn al-Ṭaylasān, con licencia de su abuelo Muhammad (n. ${ }^{\circ}$ 14), el cual la había estudiado con su suegro y autor de la obra.

Al-Sajāwī (830-902/1427-1497), por su parte, sólo proporciona el nombre y la fecha de muerte, 817/1414-15, sin citar lugar ni ningún otro dato que permita identificarlo.

17) 'Ubayd Allāh b. 'Abd Allāh b. Jalaf b. 'Ayyāš al-Anșārī, Abū Marwān ${ }^{140}$.

Natural de Córdoba, vivió en Málaga. En su biografía se dice que pertenecía a la familia del jațīb Abū 'Abd Allāh Ibn 'Ayyāš al-Šintiyālī.

Transmitió de Abū Muhammad Ibn 'Attāb ${ }^{141}$, a quien le oyó al-Muwatta' en el año 512/1118-19. Éste es el único maestro que menciona Abū Ŷa'far Ahmad b. 'Abd al-Maŷid al-Jayyār, fuente tanto de Ibn al-Abbār como de Ibn al-Zubayr, sus biógrafos. Alaban éstos sus virtudes diciendo que era un $\check{s} a y j$ de avanzada edad, piadoso, de probada virtud y religiosidad, que poseía un carácter de los mejores.

Como data de fallecimiento se puede encontrar el 1 de šawwāl del 594/6 agosto 1198 o año 574/1178-79, divergencia que debe de obedecer a un error de transmisión.

139 Al-Maqqarī, Nafh al-țīb min gusn al-Andalus al-rațīb, I. 'Abbās (ed.), Beirut, 1968, V, 263-4; al-Sajāwī, al-Daw' al-lāmi ' fì a yān al-qarn al-tāsi', Beirut [s.d.], al-ŷuz' al-tāsi' al-muŷallad al-jāmis, n. ${ }^{\circ}$ 691, 265.

140 Biografía en Takmila, ed. al-Husaynī, 937, n. ${ }^{\circ}$ 2178; ed. Codera, 538, n. ${ }^{\circ} 1514$; Ibn al-Zubayr, Silat al-Sila, III, 163, n. ${ }^{\circ} 275$.

141 Se trata de 'Abd al-Rahmān b. Muhammad b. 'Attāb b. Muhsin al-Ŷud̄āmī, hijo del prestigioso alfaquí. Cf. İ̉n Baškuwāl, Kitāb al-Șila, n. ${ }^{\circ}$ 744; al-Ḍabbī, Bugyat al-multamis, n. . 986; 'Iyāọ b. Mūsà, Gunya, 64; Tartīb al-madārik, VIII, 192. 


\section{Anexo}

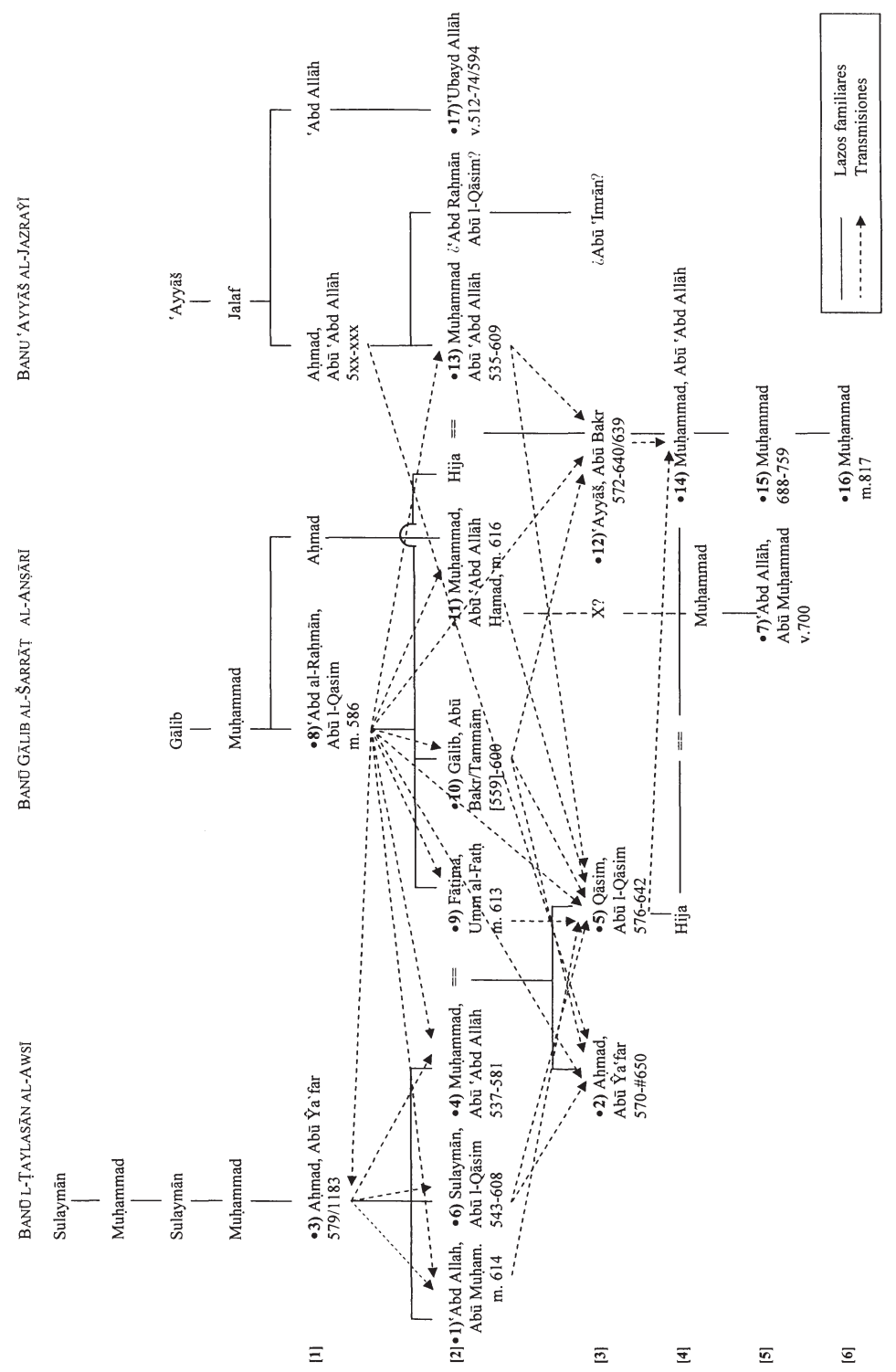

Recibido: 03/01/2007

Aceptado: 07/06/2007

Al-Qanțara (AQ) XXX 2, julio-diciembre 2009, pp. 361-401 ISSN 0211-3589 